\title{
Aminoallenylidene complexes of ruthenium(II) from the regioselective addition of secondary amines to butatrienylidene intermediates: a combined experimental and theoretical study of the hindered rotation around the $\mathrm{CN}$-bond
}

\author{
Rainer F. Winter, ${ }^{a}$ Stephan Hartmann, ${ }^{a}$ Stanislav Záliš ${ }^{b}$ and Karl Wilhelm Klinkhammer ${ }^{c}$ \\ ${ }^{a}$ Institut für Anorganische Chemie der Universität Stuttgart, Pfaffenwaldring 55, \\ D-70569Stuttgart, Germany.E-mail:winter@iac.uni-stuttgart.de \\ ' J. Heyrovský Institute of Physical Chemistry, Academy of Sciences of the Czech Republic, \\ Dolejškova 3, Prague, Czech Republic.E-mail: stanislav.zalis@jh-inst.cas.cz \\ ' Institut für Anorganische Chemie, Johannes-Gutenberg-Universität Mainz, \\ Duesbergweg 10-14, D-55099 Mainz, Germany.E-mail:klink@uni-mainz.de
}

\begin{abstract}
Aminoallenylidene complexes trans- $\left[\mathrm{Cl}(\mathrm{dppm})_{2} \mathrm{RuC}_{3}\left(\mathrm{NRR}^{\prime}\right)\left(\mathrm{CH}_{3}\right)\right]^{+}$are obtained from the regioselective addition of secondary amines to trans $-\left[\mathrm{Cl}(\mathrm{dppm})_{2} \mathrm{Ru}=\mathrm{C}=\mathrm{C}=\mathrm{C}=\mathrm{CH}_{2}\right]^{+}$. Unsymmetrically substituted amines give rise to $\mathrm{ZIE}$ isomeric mixtures. Dynamic ${ }^{31} \mathrm{P} N M R$ spectroscopy gave an energy barrier of about $85 \mathrm{~kJ} \mathrm{~mol}^{-1}$ for rotation around the $\mathrm{CN}$-bond pointing to a large contribution of the iminium alkynyl resonance form trans- $\left[\mathrm{Cl}(\mathrm{dppm})_{2} \mathrm{Ru}-\mathrm{C}=\mathrm{C}-\right.$ $\left.\mathrm{C}\left(=\mathrm{NRR}^{\prime}\right)\left(\mathrm{CH}_{3}\right)\right]^{\prime}$. This is also indicated by the pronounced bond length alternation within the $\mathrm{RuC}_{3} \mathrm{~N}$-chain as is revealed by $\mathrm{X}$-ray structure analysis of the $Z$ isomer of the (benzylmethyl)methylamine derivative $2 \mathrm{~d}$. The issue of $\mathrm{NR}_{2}$ rotation was also addressed by DFT calculations on the trans- $\left[\mathrm{Cl}(\mathrm{dhpm})_{2} \mathrm{RuC}_{3}\left\{\mathrm{~N}\left(\mathrm{CH}_{3}\right)_{2}\right\}\left(\mathrm{CH}_{3}\right)\right]^{+}$model complex $\left(\mathrm{dhpm}=\mathrm{H}_{2} \mathrm{PCH}_{2} \mathrm{PH}_{2}\right)$. Upon rotation around the iminium type $\mathrm{CN}$ bond, the nitrogen lone pair and the $\pi$-system of the allenylidene ligand are decoupled, resulting in a significantly longer $\mathrm{CN}$ bond and a tetrahedrally coordinated nitrogen atom.
\end{abstract}

\section{Introduction}

Allenylidene complexes continue to attract great attention as reactive organometallic building blocks allowing for further functionalization of the reactive cumulenylidene ligand. ${ }^{1-}$ Gratifyingly many of these transformations proceed in a highly regioselective manner. This is due to the alternation of nucleophilic and electrophilic sites along the unsaturated ligand and the directing electronic and steric influence of the transition metal moiety. While reactions of coordinatively unsaturated, yet electron rich transition metal complexes with suitably substituted propargylic alcohols according to Selegue's protocol ${ }^{5}$ provide a highly useful access route to all-carbon substituted allenylidene complexes, congeners with a heteroatom substituent attached to the allenylidene ligand cannot be prepared in this manner. Although a first aminoallenylidene complex was published as early as $1976,{ }^{6}$ more general routes were only developed during the past decade. Some involve the nucleophilic substitution of the alkoxy group of alkynyl substituted Fischer carbene complexes $(\mathrm{CO})_{5} \mathrm{M}=\mathrm{C}(\mathrm{OR})\left(\mathrm{C} \equiv \mathrm{CR}^{\prime}\right)$ by secondary amines ${ }^{7-9}$ or the Lewis-acid induced abstraction of a $\mathrm{NR}_{2}$ group from anionic complexes $\left[(\mathrm{CO})_{5} \mathrm{M}-\mathrm{C} \equiv \mathrm{C}\right.$ $\left.\mathrm{C}\left(\mathrm{NMe}_{2}\right)_{3}\right]^{-}(\mathrm{M}=\mathrm{Cr}, \mathrm{W}) \cdot{ }^{10}$ Other methods employ complexes having even more extended cumulenylidene ligands. Thus, cationic methyl or vinyl substituted aminoallenylidene complexes are formed from the regioselective addition of secondary amines to the remote $\mathrm{C}=\mathrm{CR}_{2}$ double bond of complexes $[\{\mathrm{Ru}\}=$ $\left.\mathrm{C}=\mathrm{C}_{n}=\mathrm{CR}_{2}\right]^{+}\left(n=2:\{\mathrm{Ru}\}=\mathrm{CpRu}\left(\mathrm{PPh}_{3}\right)_{2}{ }^{11,12} n=3:\{\mathrm{Ru}\}=\right.$ trans-Cl(dppe $\left.)_{2} \mathrm{Ru},{ }^{13}\{\mathrm{Ru}\}=\left(\eta^{6}-\mathrm{C}_{6} \mathrm{Me}_{6}\right) \mathrm{Ru}\left(\mathrm{PR}_{3}\right) \mathrm{Cl}^{14}\right)$. Similar reactions of neutral $\left\{(\mathrm{CO})_{5} \mathrm{Cr}=\mathrm{C}=\mathrm{C}=\mathrm{C}=\mathrm{C}=\mathrm{C}\left(\mathrm{NMe}_{2}\right)_{2}\right\}$ have also been reported. ${ }^{10}$ We have recently shown that the addition of allyl substituted tertiary amines to the carbon atom $\mathrm{C}_{\gamma}$ of the elusive primary butatrienylidene intermediates trans $-\left[\mathrm{Cl}\left(\mathrm{L}_{2}\right)_{2}\right.$ $\left.\mathrm{Ru}=\mathrm{C}=\mathrm{C}=\mathrm{C}=-\mathrm{CH}_{2}\right]^{\prime}\left(\mathrm{L}_{2}=\mathrm{dppm}\right.$, dppe, depe $)$ initially provides ammoniobutenynyl complexes trans- $\left[\mathrm{Cl}(\mathrm{dppm})_{2} \mathrm{Ru}-\mathrm{C} \equiv \mathrm{C}-\mathrm{C}-\right.$ $\left(\mathrm{NMe}_{2} \mathrm{CH}_{2} \mathrm{CH}=\mathrm{CRH}\right)=\mathrm{CH}_{2}$ ] which readily undergo Copetype rearrangement to their aminoallenylidene isomers trans $-\left[\mathrm{Cl}\left(\mathrm{L}_{2}\right)_{2} \mathrm{Ru}=\mathrm{C}=\mathrm{C}=\mathrm{C}(\mathrm{NMe})_{2}\left(\mathrm{CH}_{2} \mathrm{CRHCH}=\mathrm{CH}_{2}\right)\right]^{\prime}$. $^{15,16}$

As part of our ongoing investigations on the reactivity of the primary butatrienylidene complex trans $-\left[\mathrm{Cl}(\mathrm{dppm})_{2} \mathrm{Ru}=\mathrm{C}=-\mathrm{C}=\right.$ $\left.\mathrm{C}=\mathrm{CH}_{2}\right]^{+}$we have investigated its reactions with symmetrically and unsymmetrically substituted secondary amines $\mathrm{R}_{2} \mathrm{NH}$ and $\mathrm{RR}^{\prime} \mathrm{NH}$. The results of these studies are reported herein and include (i) the synthesis and characterization of aminoallenylidene complexes trans- $\left[\mathrm{Cl}(\mathrm{dppm})_{2} \mathrm{Ru}=\mathrm{C}=\mathrm{C}=\mathrm{C}\left(\mathrm{NRR}^{\prime}\right)\left(\mathrm{CH}_{3}\right)\right]^{*}$, (ii) the formation of $Z / E$ isomeric mixtures when unsymmetrically substituted secondary amines are employed, the latter being due to restricted rotation around the $\mathrm{C}_{\gamma} \mathrm{N}$ bond, (iii) the determination of the rotational barriers for the $Z--\rightarrow E$ $E^{--\rightarrow Z}$

and (iv) the results of a theoretical study on trans- $\left[\mathrm{Cl}(\mathrm{dppm})_{2}\right.$ $\left.\mathrm{Ru}=\mathrm{C}=\mathrm{C}=\mathrm{C}\left\{\mathrm{N}\left(\mathrm{CH}_{3}\right)_{2}\right\}\left(\mathrm{CH}_{3}\right)\right]^{+}$and trans $-\left[\mathrm{Cl}(\mathrm{dhpm})_{2} \mathrm{Ru}=\mathrm{C}=\mathrm{C}=\right.$ $\left.\mathrm{C}\left\{\mathrm{N}\left(\mathrm{CH}_{3}\right)_{2}\right\}\left(\mathrm{CH}_{3}\right)\right]^{+}$(dhpm $\left.=\mathrm{H}_{2} \mathrm{PCH}_{2} \mathrm{PH}_{2}\right)$. The latter model complex was introduced in order to address the energy barrier to rotation around the $\mathrm{C}_{\mathrm{y}} \mathrm{N}$ bond. The $Z$-isomer of the $N$-benzylmethylamine derived complex was also characterized by $\mathrm{X}$-ray analysis.

\section{Results and discussion}

Aminoallenylidene complexes: trans-[Cl(dppm $)_{2}-$ $\left.\mathrm{Ru}=\mathrm{C}=\mathrm{C}=\mathrm{C}\left(\mathrm{NR}_{2}\right)\left(\mathrm{CH}_{3}\right)\right]^{+}$

The trapping of the primary butatrienylidene complexes trans- $\left[\mathrm{Cl}(\mathrm{dppm}){ }_{2} \mathrm{Ru}=\mathrm{C}_{u}=\mathrm{C}_{\beta}=\mathrm{C}_{\gamma}=\mathrm{C}_{\delta} \mathrm{H}_{2}\right]^{4}$ by secondary amines follows the general pathway observed for the addition of protic nucleophiles to like species. ${ }^{11,12,17-19}$ In each case the amine regioselectively adds to carbon atom $\mathrm{C}_{p}$, which has been attributed to a favourable combination of electronic and steric 


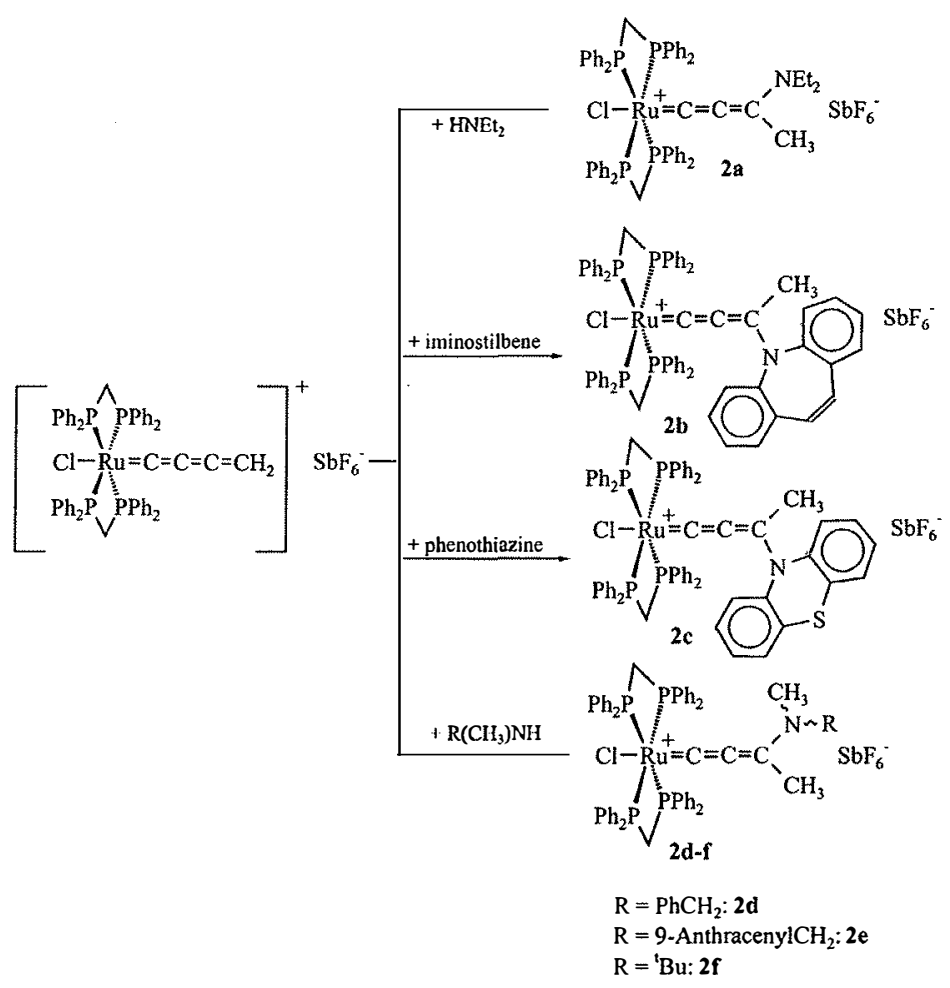

Scheme 1

effects. $^{1}$

from the ammonium site to the neighbouring methylene group to afford aminoallenylidene complexes trans $-\left[\mathrm{Cl}(\mathrm{dppm}){ }_{2} \mathrm{Ru}=\mathrm{C}=\right.$ $\left.\mathrm{C}=\mathrm{C}\left(\mathrm{NRR}^{\prime}\right)\left(\mathrm{CH}_{3}\right)\right]^{\prime}(\mathbf{2 a}-\mathrm{f})$ as greenish to orange yellow air stable solids after appropriate workup (Scheme 1). In contrast to the addition/Cope-type rearrangement sequence observed with allyl substituted tertiary amines as trapping agents ${ }^{15,16}$ we have not been able to detect the primary addition products trans $-\left[\mathrm{Cl}(\mathrm{dppm})_{2} \mathrm{Ru}-\mathrm{C} \equiv \mathrm{C}-\mathrm{C}\left(\mathrm{NRR} \mathrm{R}^{\prime} \mathrm{H}\right)=\mathrm{CH}_{2}\right]^{+21}$ by either ${ }^{31} \mathrm{P}$ NMR or IR spectroscopies. Proton migration from the primary addition product may occur via a deprotonation/reprotonation sequence catalysed by the excess amine. This would account for the lower lifetime of such an intermediate. Much to our surprise, the diethylamino substituted complex $2 \mathbf{a}$ was also formed in good yield from the trapping of the butatrienylidene intermediate by 4 -(diethylaminomethyl)-2,5-dimethylphenol. This process requires desamination of the primary addition product as is shown in Scheme 2. 4-Methylene-2,5-dimethylcyclohexadienone or 2,5,2',5'-tetramethylstilbene-4,4'-diol may be envisioned as the organic byproducts. All our attempts to verify the formation of any of these have not led to unambiguous results. Since 4-alkylidenecyclohexadienones are accessible from 4-chloromethylphenols by base promoted $\mathrm{HCl}$ elimination, ${ }^{22}$ a similar degradation of the primarily formed organometallic ammonium salt with concomitant formation of the reactive quinoidal ketone constitutes a likely pathway for this degradation step.

In their IR spectra the CCC-valence band of the unsaturated ligand often referred to as the "allenylidene stretch" is observed as a highly intense band at $1992 \mathrm{~cm}^{-1}$ for the diethylamino substituted complex 2a but at considerably lower energies (1967 and $1941 \mathrm{~cm}^{-1}$ ) for the iminostilbene and phenothiazine derived complexes $\mathbf{2 b}, \mathbf{c}$. The same holds for another prominent feature which appears at $c a \cdot 1550-1570 \mathrm{~cm}^{-1}$ for alkylamino substituted allenylidene complexes but is shifted to $c a .1490 \mathrm{~cm}^{-1}$ for complexes 2b,c. Our previously reported calculations at the DFT level of theory have shown that the band at higher energy mainly involves the $\mathrm{C}_{\alpha} \mathrm{C}_{\beta}$ bond, reflecting the bond order at this specific position. ${ }^{16}$ The band near $1550 \mathrm{~cm}^{-1}$ has been assigned to a vibration involving the $\mathrm{C}_{\gamma} \mathrm{N}$ stretch as well as angular distortions of the substituents attached to these atoms. ${ }^{16}$ Taken together, a red shift of both these absorption signals a lower contribution of the alkynyl type resonance forms II and III in Chart 1 for aminoallenylidene complexes with less electron donating amino moieties. Similar trends prevail in ${ }^{13} \mathrm{C}$ NMR and UV/Vis spectroscopies. The higher cumulenylidene character of $\mathbf{2 b}, \mathbf{c}$ results in a sizable downfield shift of the $\mathrm{C}_{u}$ resonance signal by $c a$. $25 \mathrm{ppm}$. Likewise, the optical absorption bands due to the HOMO $\rightarrow$ LUMO and the HOMO$1 \rightarrow$ LUMO transitions move to lower energies by $c a .1500 \mathrm{~cm}^{-1}$ as compared to other allenylidene complexes bearing alkyl substituted amino groups. ${ }^{16}$ Similar, but even stronger effects have been observed when $\mathrm{NR}_{2}$ substituents are replaced by $\mathrm{SR}$ and SeR moieties, which are even less potent $\pi$-donors. ${ }^{35,36}$
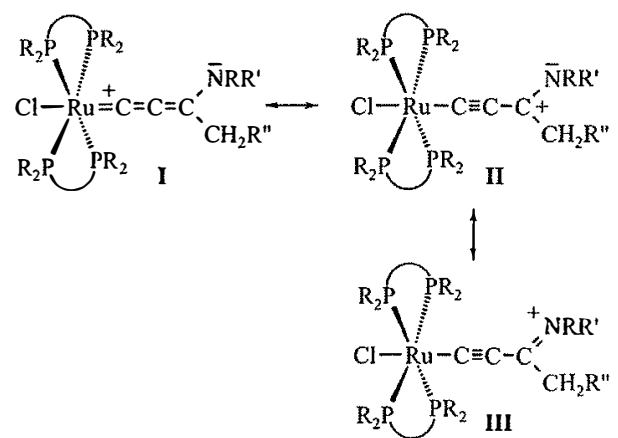

Chart 1

In their ${ }^{31} \mathrm{P}$ NMR spectra the heterocyclically substituted complexes $\mathbf{2 b , c}$ display an $\mathrm{AA}^{\prime} \mathrm{BB}^{\prime}$ multiplet. This is in sharp contrast to all other complexes within this series where the four $\mathrm{P}$ atoms are equivalent and give rise to only a singlet resonance. Signal patterns of this type point to the presence of a chiral 


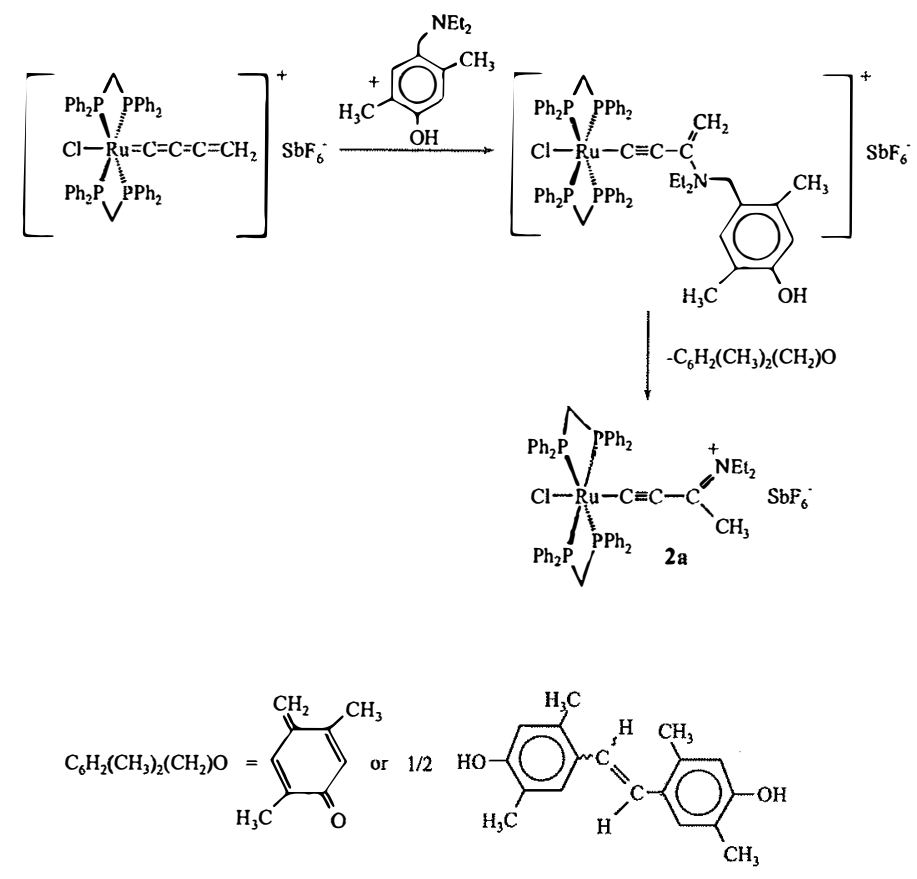

Scheme 2

element within the ligand backbone. ${ }^{21}$ In $\mathbf{2 b , c}$ this asymmetry presumably arises from the relative orientations of the two planes defined by the metal atom, the carbon atoms of the unsaturated ligand and the atoms linked to $\mathrm{C}_{y}$ on one hand and the ring plane of the heterocycle on the other. This is schematically shown in Chart 2 where the solid bar represents the plane of the organic heterocycle. Interconversion between the two enantiomers requires rotation around the $\mathrm{C} . \mathrm{N}$ bond. This process is, however, slow on the NMR timescale. ${ }^{16}$ Upon warming a solution of $2 \mathbf{b}$ in $\mathrm{CD}_{3} \mathrm{NO}_{2}$ to $368 \mathrm{~K}$ no broadening of the individual resonance lines of either the multiplet signal in the ${ }^{31} \mathrm{P}$ NMR or the resonance signals in the ${ }^{1} \mathrm{H}$ NMR spectra were observed. Judging from the shift difference of $36.5 \mathrm{~Hz}$ between the two olefinic

two arene rings, the rotational barrier must well exceed $78 \mathrm{~kJ}$ $\mathrm{mol}^{-1}$.

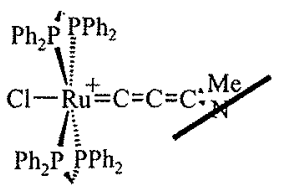<smiles>CC(C)C#C[P+](Cl)([PbH])[PbH]</smiles>

Chart 2

Hindered rotation around this bond is, however, not restricted to derivatives with bulky substituents on the nitrogen atom but may be attenuated by these. In several $\mathrm{NMe}_{2}$ substituted derivatives and in the diethyl substituted complex 2a the nitrogen bound substituents were always found to be nonequivalent, even at elevated temperature. We note that the room-temperature NMR spectra of neutral aminoallenylidene complexes of the $\operatorname{Cr}(\mathrm{CO})_{5}$ moiety also indicate the presence of magnetically inequivalent amine substituents. ${ }^{710}$ High barriers to rotation around the $\mathrm{C}_{y}-\mathrm{N}$ bond thus seem to be an intrinsic property of these systems. In this respect, complexes $\mathbf{2 b}, \mathbf{c}$ do not differ from their aliphatic counterparts.

\section{Derivatives: trans $^{-}\left[\mathrm{Cl}(\mathrm{dppm})_{2} \mathrm{Ru}=\mathrm{C}=\mathrm{C}=\mathrm{C}\left(\mathrm{NRR}^{\prime}\right)\left(\mathrm{CH}_{3}\right)\right]^{+}$}

Due to hindered rotation around the $\mathrm{C}_{\gamma} \mathrm{N}$ bond, the addition of unsymmetrically substituted secondary amines results in the formation of the corresponding aminoallenylidene complexes as $E / Z$ isomeric mixtures. Conjugation across the $\mathrm{C}_{3} \mathrm{~N}$ ligand requires that the $N R R^{\prime}$ group is nearly coplanar with the $\mathrm{RuC}_{3} \mathrm{~N}$ plane. In this conformation one of the substituents on the nitrogen atom inevitably points toward the diphosphine ligands, leading to unfavourable steric interactions. The $E / Z$ selectivity of the equilibrated isomeric mixtures therefore depends on the difference

substituents and increases from $3: 2$ for the benzylmethyl derivative $2 \mathrm{~d}$ to $2: 1$ for the (9-anthracenylmethyl)methyl derivative $2 \mathrm{e}$ and to $7: 3$ for the tert-butylmethyl amine derivative 2 f. The isomeric ratios were determined from the crude reaction products. Recrystallization or chromatographic workup resulted in a partial separation of these isomers and the isolation of the pure $Z$ isomer of the benzylmethyl amine derivative as dark yellow crystals. Spectroscopic studies on samples differing in their $Z / E$ ratios allowed us to assign all crucial resonance signals to the individual isomers.

In each case the ${ }^{1} \mathrm{H}$ NMR resonances of substituents pointing toward the dppm ligands appear at comparatively higher field. This can be traced back to the aromatic ring current of the nearby phenyl rings. The $N$-benzylmethylamine derivative 2d illustrates this point: The $Z$ isomer with the benzyl ring oriented toward the transition metal moiety shows singlet signals at $\delta 2.68 \mathrm{ppm}$ for the $\mathrm{NCH}_{3}$ and at $\delta 3.93 \mathrm{ppm}$ for the $\mathrm{NCH}_{2}$ protons whereas these resonances are located at $\delta 2.13$ and 4.69 ppm for the $E$ isomer. Similar trends are observed in their ${ }^{13} \mathrm{C}$ NMR spectra. Furthermore, each isomer displays a separate singlet signal in the ${ }^{31} \mathrm{P}$ NMR spectrum. These different resonances are, however, very closely spaced. In dynamic NMR the coalescence temperature increases with the shift difference between the resonances of those groups that are directly involved in the dynamic process. Their close proximity thus provided another opportunity to experimentally determine the activation energies associated with rotation around the $\mathrm{C}_{y} \mathrm{~N}$ bond. In the case of the tert-butylmethyl derivative $2 \mathrm{f}$ we finally succeeded. Upon warming a solution of this complex in 1,2$\mathrm{C}_{2} \mathrm{D}_{2} \mathrm{Cl}_{4}$ the two singlet resonance signals first broaden and finally coalesce at $T=398 \mathrm{~K}$. At even higher temperatures the singlet resonance signal reversibly sharpens (Fig. 1).

In order to extract activation energies from these data one has to rely on a model that accounts for the presence of two 


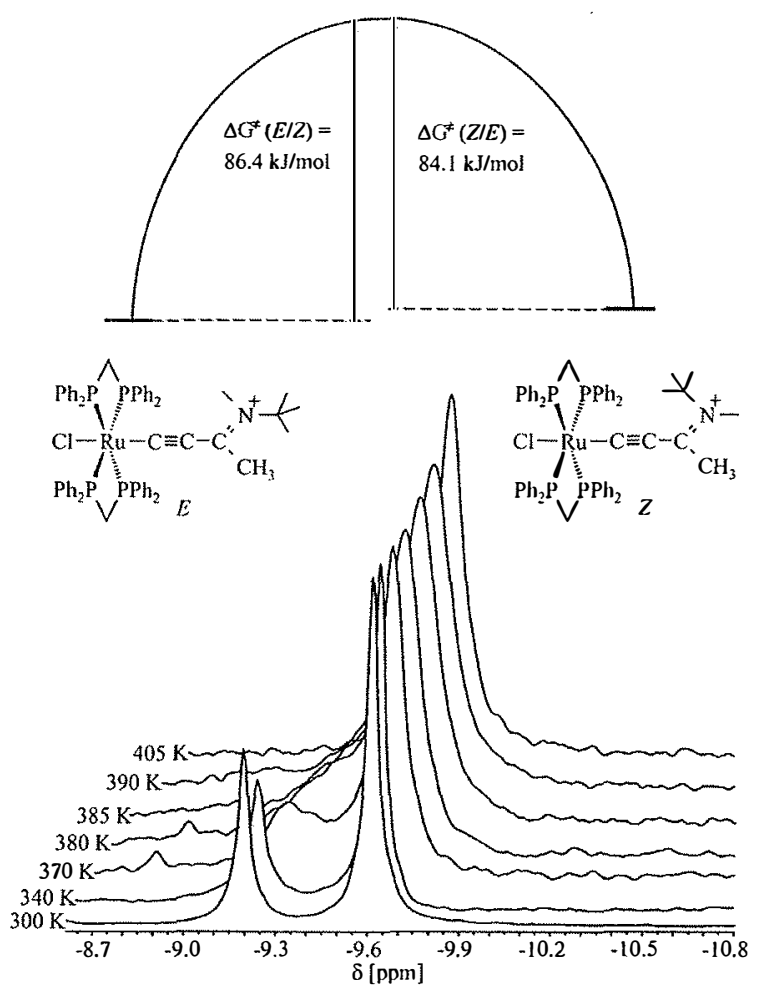

Fig. 1 Dynamic ${ }^{31}$ P NMR investigations on compound $2 f$.

energetically distinct and unequally populated states. This requires determining the resonance frequencies for both isomers over a wide temperature range. Within a regime sufficiently below the coalescence temperature $T_{c}$ the shift difference between the individual isomers is a linear function of temperature. Extrapolation to $T_{\mathrm{c}}$ furnishes the theoretical shift difference $\Delta v_{\text {th }}$ at $T=T_{\mathrm{c}}$. The rate constants for the mutual interconversion between the two isomers are available from eqns. (1) and (2), where $\Delta v$ represents the difference in resonance frequencies and $\Delta p$ is the difference in the population of the energetically distinct states. The parameter $X$ depends on $\Delta p$ and may be taken from tabulated values. ${ }^{23}$ The free energies of activation $\Delta G^{*}$ are then available from the rate constants as given by eqns. (3) and (4). ${ }^{24}$ Here, $k_{\mathrm{b}}$ is the Boltzmann constant, $h$ the Planck constant and $\kappa$ the transmission factor which is usually set as equal to unity.

$$
\begin{gathered}
k_{Z \longrightarrow E}=\pi \Delta v X^{-1}(1-\Delta p) \\
k_{E-Z}=\pi \Delta v X^{-1}(1+\Delta p) \\
k_{Z \rightarrow E}=\kappa k_{\mathrm{b}} T_{\mathrm{c}} h^{-1} \exp \left(-\Delta G_{Z \rightarrow E_{E}}^{\prime} R^{-1} T^{-1}\right) \\
k_{E \rightarrow Z}=\kappa k_{\mathrm{b}} T_{\mathrm{c}} h^{-1} \exp \left(-\Delta G_{E \rightarrow Z}^{\prime} R^{-1} T^{-1}\right)
\end{gathered}
$$

According to this procedure, the barriers to rotation were determined as $86.4(E \longrightarrow Z)$ and $84.1 \mathrm{~kJ} \mathrm{~mol}^{-1}(Z \longrightarrow E)$, giving an energy difference of $2.3 \mathrm{~kJ} \mathrm{~mol}^{-1}$ for the two isomers. For all other compounds the spacing of the resonance signals for the individual isomers was larger and did not allow us to access the free rotation limit. We note that the energy barriers obtained for $2 \mathrm{f}$ are somewhat lower as those observed for organic imines. ${ }^{25}$ They agree, however, well with values reported for donor substituted iminium salts like the $N, N$-dimethyl(methylthio) and $N, N$-dimethylamino(methoxy) derivatives $\left(\mathrm{Me}_{2} \mathrm{~N}\right)(\mathrm{EMe}) \mathrm{C}=\mathrm{NMe}_{2}{ }^{+}(\mathrm{E}=\mathrm{O}, \mathrm{S}){ }^{26}$ Despite their distinct NMR spectroscopic characteristics, only one CCC and $\mathrm{C}=\mathrm{N}$ band in their IR spectra and only one oxidation wave in cyclic voltammetry (vide infra) were observed for the isomeric mixtures. Obviously the influence of the relative orientations of the different substituents on the nitrogen atom on these properties is too small to be resolved.

\section{Structural characterization of trans $-Z-\left[C l(d p p m){ }_{2} \mathrm{Ru}=\mathrm{C}=\mathrm{C}=\mathrm{C}\right.$ -} $\left.\left(\mathrm{NMeCH}_{2} \mathrm{Ph}\right)\left(\mathrm{CH}_{3}\right)\right]^{+} \mathrm{SbF}_{6}^{-}$

Dark yellow crystals of the $Z$ isomer of the benzylmethylamine derivative $2 \mathbf{d}$ were obtained upon slow concentration of a solution in dichloromethane-diethyl ether and investigated by $\mathrm{X}$-ray crystallography. A plot of the complex cation is shown in Fig. 2 while pertinent bond parameters are given as Table 1 . Common structural features of aminoallenylidene complexes are a pronounced bond length alternation along the $\mathrm{C}_{3}$ chain of the unsaturated ligand, a rather long $\mathrm{Ru}-\mathrm{C}_{u}$ bond and, most notably, a planar coordination of the nitrogen atom at tached to $C_{\gamma}$. These mirror the strongly dipolar character of neutral congeners ${ }^{6,8-10,27}$ and the dissipation of the positive charge over the $\mathrm{MC}_{3} \mathrm{~N}$ chain in cationic derivatives such as the aminoallenylidene complexes discussed herein. ${ }^{12,16}$ The complex cation of Z-2d fully adheres to these trends. Thus, the $\mathrm{Ru}-\mathrm{C}(1)$ bond length of $1.947(6) \AA$ is shorter than those typically observed in alkynyl complexes of the same metal entity (1.994-2.078 $\AA){ }^{28}$ but long with respect to related all-carbon substituted derivatives $\left.[\{\mathrm{Ru}\}=\mathrm{C}=\mathrm{C}=\mathrm{CRR}]^{\prime}\right]^{+}\left(\mathrm{R}, \mathrm{R}^{\prime}=\right.$ alkyl, aryl; 1.84-1.903 $\AA$ ). ${ }^{2}$ While the $C(1)-C(2)$ bond of $1.217(9) \AA$ is only slightly long with respect to a typical $\mathrm{C} \equiv \mathrm{C}$ triple bond (average value 1.189 $\AA$ ) the $\mathrm{C}(2)-\mathrm{C}(3)$ distance of $1.398(9) \AA$ is significantly longer than a $\mathrm{C}=\mathrm{C}$ double bond $(d(\mathrm{C}=\mathrm{C})$ in allenes $=1.307 \AA)$ and resembles a single bond between an $\mathrm{sp}$ and an $\mathrm{sp}^{2}$ hybridized carbon atom $(1.431 \AA){ }^{29}$ Moreover, the $\mathrm{C}(3)-\mathrm{N}$ bond $(1.290(10) \AA)$ is much shorter than the N-C bonds to the methyl and the benzylic methylene carbon atoms $(\mathrm{C}(5)-\mathrm{N} 1.432(12)$ and $\mathrm{C}(41)-\mathrm{N} 1.512(9) \AA)$. Along with the strictly planar coordination of the nitrogen atom this provides further compelling evidence of a distinct iminium-like character of the NRR' group. This latter entity is nearly, but not exactly, coplanar to the plane containing the carbon atoms $C(1)$ to $C(3)$, and the nitrogen and the ruthenium atoms, as follows from the torsional angle $\mathrm{C}(2)-\mathrm{C}(3)-\mathrm{N}-\mathrm{C}(5)$ of $7.2^{\circ}$. The distance $\mathrm{C}(3)-\mathrm{C}(31)$ of $1.526(10) \AA$ lies in the range typical of a $C\left(\mathrm{sp}^{2}\right)-\mathrm{C}\left(\mathrm{sp}^{3}\right)$ single bond. $^{29}$

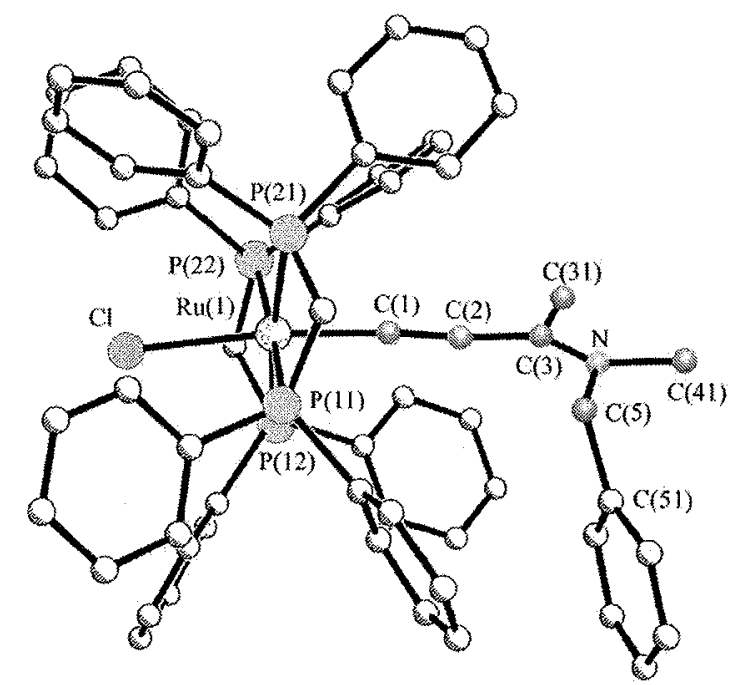

Fig. 2 Structure of the cation of Z-trans- $\left[\mathrm{Cl}(\mathrm{dppm})_{2} \mathrm{RuCCC}\right.$ $\left(\mathrm{NMeCH}_{2} \mathrm{Ph}\right)\left(\mathrm{CH}_{3}\right)^{+}$as determined by $\mathrm{X}$-ray crystallography.

A closer inspection of the structure of compound 2d explains the rather low $E / Z$ selectivity of $3: 2$. In the solid state the phenyl group is rotated away from the phenyl rings on the dppm 
Table 1 Comparison between selected bond lengths $(\AA)$ and angles $\left(^{\circ}\right)$ for the cation in complex $4 \mathbf{d}$ and the values calculated for trans $-\left[\mathrm{Cl}(\mathrm{dppm})_{2} \mathrm{RuC}_{3}\left\{\mathrm{~N}\left(\mathrm{CH}_{3}\right)_{2}\left(\mathrm{CH}_{3}\right)\right]^{\prime}\right.$ by the $\mathrm{ADF} / \mathrm{BP}$ method (square brackets)

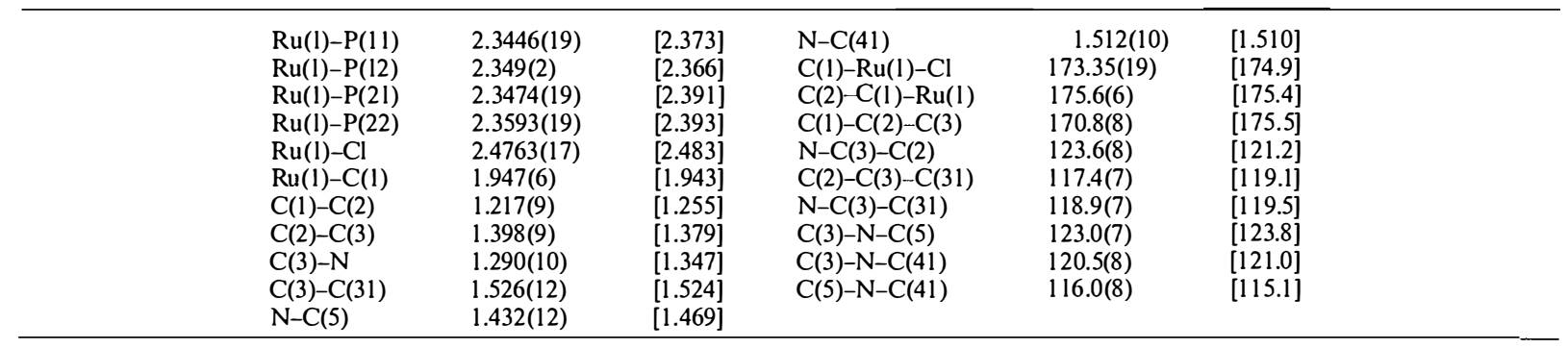

Table 2 Electrochemical data for complexes $2 \mathbf{a}-\mathbf{f}$ in $\mathrm{CH}_{2} \mathrm{Cl}_{2}$ solution

\begin{tabular}{llll}
\hline & $E_{1 / 2}{ }^{+/ 2 w} / \mathrm{V}$ & $E_{1 / 2}{ }^{+10} / \mathrm{V}$ & $E_{\text {follow }} / \mathrm{V}$ \\
\hline $\mathbf{2 a}$ & +0.41 & $-2.33^{a}$ & $-2.63^{d}$ \\
$\mathbf{2 b}$ & +0.77 & $-1.955^{b, c}$ & $-1.34^{d},-0.025^{e}$ \\
$\mathbf{2 c}$ & $+0.79^{b}$ & $-1.625^{b, c}$ & $-0.04^{d}$ \\
$\mathbf{2 d}$ & +0.585 & - & - \\
& $+0.525^{f}$ & $-2.17^{c}$ & $-1.35^{d}$ \\
$\mathbf{2 e}$ & +0.520 & -2.19 & \\
$\mathbf{2 f}$ & $+0.56^{b}$ & - &
\end{tabular}

a Partially reversible at $195 \mathrm{~K} .{ }^{h}$ Partially reversible at $298 \mathrm{~K}$. 'Suffers from slow elect ron transfer kinetics. ${ }^{d}$ Irreversible peak following reduction. "Wave of a (partially) reversible couple following reduction. ${ }^{f} \mathrm{In} \mathrm{THF}-\mathrm{NBu}_{4} \mathrm{PF}_{6}$

ligands such that the benzyl group provides only little more steric hindrance than a methyl substituent. For the related anthracenylmethyl derivative $2 \mathrm{e}$ the orientation is likely the same. The more extended fused ring system increases the steric hindrance in the $Z$ isomer such that the $E / Z$ selectivity is larger. In the $Z$ isomer of the tert-butylmethyl derivative $2 \mathrm{f}$ one of the methyl groups at the tert-butyl substituent inevitably points toward the dppm ligand which further enhances steric discrimination between the two isomers

\section{Electrochemical and spectroelectrochemical investigations}

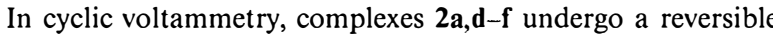
one-electron oxidation at potentials ranging from +0.41 to $+0.59 \mathrm{~V} v s$. the ferrocene-ferrocenium couple (Table 2). With reference to our earlier studies on closely related derivatives trans $-\left[\mathrm{Cl}(\mathrm{dppm})_{2} \mathrm{Ru}=\mathrm{C}=\mathrm{C}=\mathrm{C}\left(\mathrm{NR}_{2}\right)\left(\mathrm{C}_{2} \mathrm{H}_{4} \mathrm{CH}=\mathrm{CH}_{2}\right)\right]^{+} \quad(\mathrm{R}=\mathrm{Me}$, $\mathrm{C}_{5} \mathrm{H}_{10}$ ) this process may be viewed as the $\mathrm{Ru}(\mathrm{II} / \mathrm{III})$ couple. ${ }^{16}$ Complexes $\mathbf{2 d - f}$ which exist as $Z / E$ isomeric mixtures display only one slightly broadened anodic wave in cyclic voltammetry, square wave or differential pulse voltammetry experiments, the individual isomers being indistinguishable by electrochemical techniques.

The oxidation of complex 2a has been followed by simultaneous IR monitoring in an in situ spectroelectrochemical experiment. Upon oxidation the "allenylidene band" shifts by $45 \mathrm{~cm}^{-1}$ to lower energy $\left(v_{\mathrm{ccc}}=1948 \mathrm{~cm}^{-1}\right)$ along with a considerable absorptivity loss. The iminium type $\mathrm{C}=\mathrm{N}$ band shows contrasting behaviour, moving to higher energy (from 1557 to $1597 \mathrm{~cm}^{-1}$ ) and retaining its original absorptivity (see also Table 3). Subsequent reduction regenerates the bands of the starting material in $c a .85 \%$ optical yield. These results are best accommodated by invoking the two mesomeric resonance forms IV and V (Chart 3). Both agree with the results from

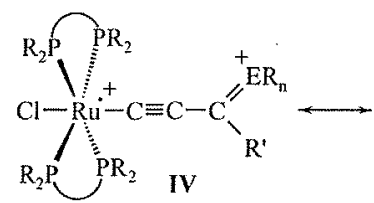

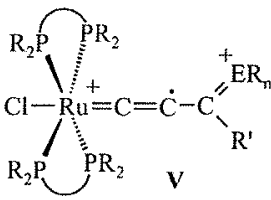

Chart 3 theoretical calculations in placing the unpaired spin on either the metal or the $\beta$-carbon atom and with the IR results in retaining (or even strengthening) the $\mathrm{C}=\mathrm{N}$ double bond. In UV/ Vis spectroelectrochemistry a blue shift of both absorption bands in the visible regime is observed, the band at higher energies now appearing as a shoulder superimposed on the phosphine based transitions. The results are virtually identical to those for the related piperidinyl substituted complex trans$\left[\mathrm{Cl}(\mathrm{dppm})_{2} \mathrm{Ru}=\mathrm{C}=\mathrm{C}=\mathrm{C}\left\{\mathrm{N}\left(\mathrm{C}_{5} \mathrm{H}_{10}\right)\right\}\left(\mathrm{C}_{2} \mathrm{H}_{4} \mathrm{CH}=\mathrm{CH}_{2}\right)\right]^{+}$or similar derivatives. ${ }^{16}$

Complexes $\mathbf{2 b}, \mathbf{c}$ in which the nitrogen atom is part of a less basic unsaturated heterocycle are oxidized at considerably higher potentials of +0.77 (2b) or $+0.79 \mathrm{~V}$ (2c) (Fig. 3). If one assumes that the predominantly metal centred nature of the anodic oxidation process is still retained in $\mathbf{2 b} \mathbf{b}, \mathbf{c}$, this finding provides evidence for effective conjugation along the ruthenabutatriene chain. The electronic properties of the amine (iminium) substituents are thus effectively transmitted from the iminium to the $\left\{\mathrm{Cl}(\mathrm{dppm})_{2} \mathrm{Ru}\right\}$ sites across the $\mathrm{C}_{3}$ chain. Some ambiguity as to the oxidation site, however, arises from the fact that the parent heterocyclic amines are themselves electroactive, being oxidized at even less anodic potentials than is typically the case for the aminoallenylidene complexes under study. ${ }^{30,31}$ In principle, $\mathbf{2 b}, \mathbf{c}$ therefore might form mixed-valent species exhibiting intramolecular electron transfer between an organic and a (predominantly) inorganic redox site. ${ }^{32}$
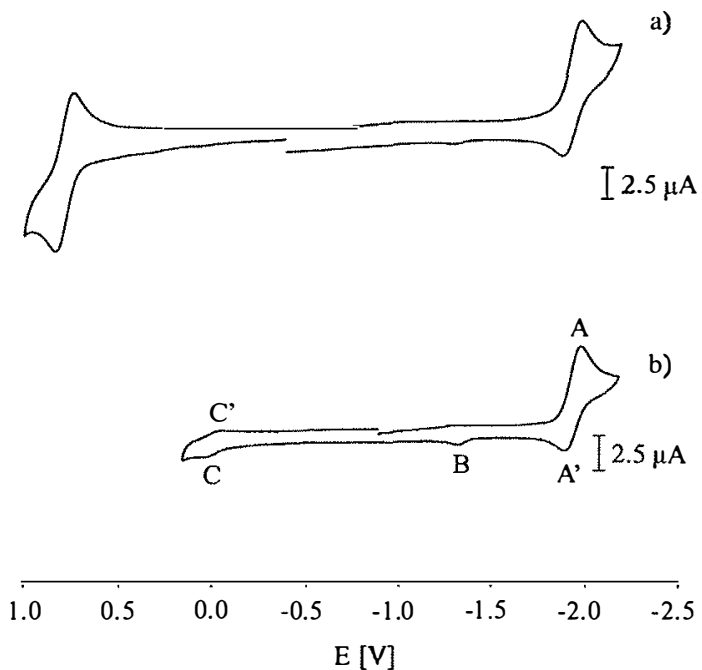

Fig. 3 Cyclic voltammogram of compound $2 \mathrm{~b}$ : (a) $v=0.75 \mathrm{~V} \mathrm{~s}^{-1}$ at ambient temperature and (b) cathodic scan at $v=0.4 \mathrm{~V} \mathrm{~s}^{-1}$ at ambien temperature.

Evidence from spectroelectrochemical studies, however, argues against any involvement of the heterocylic substituent in the oxidation process. Spectroscopic changes upon oxidation are qualitatively identical as for complexes with aliphatic substituents on the iminium nitrogen atom as is exemplified for complex 2b. In IR spectroscopy (see Fig. 4) the allenylidene band 
Table 3 Results from spectroelect rochemical studies on compounds $2 \mathrm{a}$, b in $1,2-\mathrm{C}_{2} \mathrm{H}_{4} \mathrm{Cl}_{2}-\mathrm{NBu}_{4} \mathrm{PF}_{6}$ at $293 \mathrm{~K}^{a}$

\begin{tabular}{llll} 
& $v_{\mathrm{CCC}}{ }^{b} / \mathrm{cm}^{-1}$ & $v_{\mathrm{C}=\mathrm{N}}{ }^{b} / \mathrm{cm}^{-1}$ & $\lambda_{\max } / \mathrm{nm}\left(\varepsilon_{\max } / \mathrm{dm}^{3} \mathrm{~mol}^{-1} \mathrm{~cm}^{-1}\right)^{c}$ \\
\hline $\mathbf{2 a}$ & $1993(\mathrm{vs})$ & $1557(\mathrm{~m})$ & $623(400), 393(14200), 266(45000)$ \\
$\mathbf{2 a}$ & $1948(\mathrm{w})$ & $1597(\mathrm{~m})$ & $565(2500), 333(13500), 271(38000)$ \\
$\mathbf{2 b}$ & $1962(\mathrm{vs})$ & $1494(\mathrm{~m})$ & $655(640), 506(\mathrm{sh}, 555), 426(23800), 300(\mathrm{sh}, 18400), 269(55000)$ \\
$\mathbf{2} \mathbf{b}^{+}$ & $1901(\mathrm{w})$ & $1542(\mathrm{~m})$ & $600(2300), 350(17500), 284(49000)$ \\
$\mathbf{2} \mathbf{b}^{-}$ & $2055(\mathrm{w}), 2073(\mathrm{w})$ & None & $433(\mathrm{sh}, 10000), 336(\mathrm{sh}, 12500), 264(44000)$
\end{tabular}

${ }^{a}$ Note that the complexes $\mathbf{2 a}, \mathbf{b}$ are monocations, such that the oxidized or reduced species are dicationic or neutral, respectively. ${ }^{h} \mathrm{As} \mathrm{KBr}$ pellet. ' In $1,2-\mathrm{C}_{2} \mathrm{H}_{4} \mathrm{Cl}_{2}$.

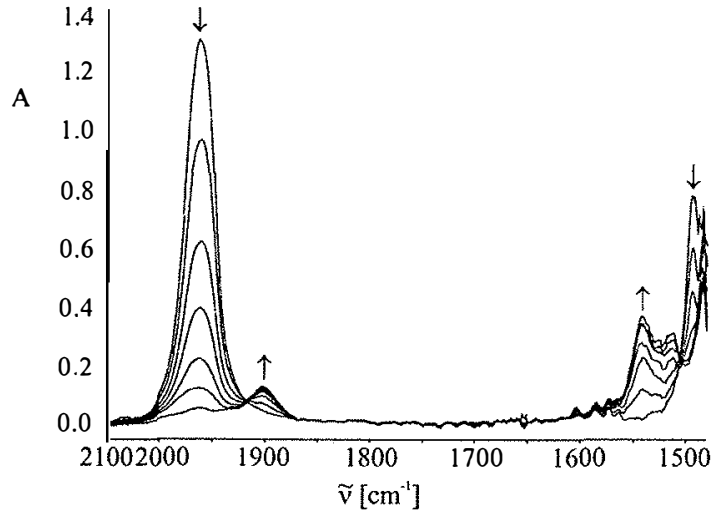

Fig. 4 IR spect ra recorded during the oxidation of complex $\mathbf{2 b}$.

shifts by some $60 \mathrm{~cm}^{-1}$ to lower energy with, again, considerable loss in intensity. The intensity loss probably arises from the fact that the unsaturated ligand bridges two positively charged centres (i.e. the Ru atom and the iminium moiety) in the oxidized state, while only one positively charged entity is present in the monocationic Ru(II) species. This reduces the dipole moment change during the $\mathrm{C}_{3}$ valence stretch. Similarly, the CCC-band is reportedly much weaker in neutral allenylidene complexes than in monocationic ones. ${ }^{33}$ The same holds for the $\mathrm{C} \equiv \mathrm{C}$ stretch of apolar alkynyl complexes when compared to polar ones. ${ }^{34}$ As for $2 \mathrm{a}$, oxidation is also accompanied by a high-energy shift of the $\mathrm{C}=\mathrm{N}$ band from 1494 to $1542 \mathrm{~cm}^{-1}$. This indicates a further enhancement of the iminium character in the oxidized state and clearly argues against a ligand centred oxidation process. Similarly to other alkylamino substituted allenylidene complexes, the absorption bands in the visible regime are shifted to higher energies upon oxidation as revealed by UV/Vis spectroelectrochemistry. The lower energy band (the HOMO $\rightarrow$ LUMO transition) gains in intensity while the absorptivity of the second band (the HOMO - $1 \rightarrow$ LUMO transition) decreases (Fig. 5). We note that the trend toward red shifted absorption bands of derivatives with less electron

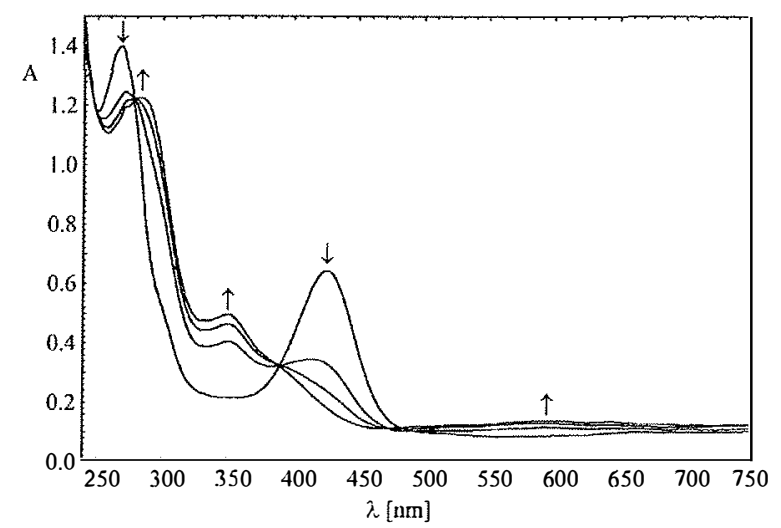

Fig. 5 UV/Vis spectra recorded during the oxidation of complex $\mathbf{2 b}$. donating substituents is also retained in the $\mathrm{Ru}(\mathrm{III})$ forms as follows from the comparison between the oxidized forms of complexes $\mathbf{2 a}$ and $\mathbf{2 b}$ (see Table 3 ). We therefore conclude that for the heterocyclically substituted derivatives the oxidation process still has predominant metal character. Conversion of the heterocyclic amines to iminium type derivatives obviously leads to a strong anodic shift of the oxidation potentials of the heterocyclic moiety. In fact, we have not found any additional anodic wave up to the discharge limit of the supporting electrolyte solution.

The lesser electron donating character of the $\mathrm{NR}_{2}$ moiety in compounds $\mathbf{2 b}, \mathbf{c}$ also leaves its mark on their cathodic behaviour. While the reduction of complexes $2 \mathbf{a}$ and $\mathbf{2 d - \mathbf { f }}$ occurs close to the cathodic solvent limit and is followed by fast chemical processes as was observed for similar derivatives (Table 2) ${ }^{16} \mathbf{2 b}, \mathbf{c}$ are reduced at considerably less negative potentials. More significantly, the reduction waves are partially reversible even under ambient conditions and at low sweep rates as is illustrated for compound $\mathbf{2 b}$ in Fig. 3. At higher sweep rates or upon cooling the chemical follow reactions are efficiently suppressed, rendering the reduction chemically and electrochemically reversible. At lower sweep rates and ambient temperature additional peaks/waves are observed during the reverse scan following reduction (peaks B and $\mathrm{C} / \mathrm{C}^{\prime}$ in Fig. 3(b)).

Since complexes $\mathbf{2 b , c}$ offer at least partial reversibility in their electrochemical reduction it was of interest to investigate this process under the same in situ IR-conditions. Upon reduction, the IR band of the allenylidene ligand collapses with the concomitant formation of two considerably less intense absorptions at 2057 and $2073 \mathrm{~cm}^{-1}$ (ESI, $†$ Fig. Sl(a)). Both are typical of neutral alkynyl species. These results agree nicely with our observations on the reduction of sulfur ${ }^{35}$ and selenium substituted $^{36}$ allenylidene complexes and studies on the chemical reduction of carbon substituted allenylidene complexes by the Touchard group. ${ }^{37}$ Reoxidation was performed by slowly sweeping the potential after exhaustive reduction and occurs in a stepwise fashion: the species displaying the lower energy IR band is consumed first with partial regeneration of the starting material. Most interestingly, the second product with the IR band at $2073 \mathrm{~cm}^{-1}$ is also converted back to $\mathbf{2 b}$ upon oxidation at a more positive potential. This is indicated by the growth of the original allenylidene IR band (ESI, †Fig. Sl(b)) with the concomitant collapse of the alkynyl band at $2073 \mathrm{~cm}^{-1}$. For solutions as concentrated as for the experiment shown in Fig. 6 the optical yield of the regenerated starting material was only about $60 \%$ but better results (recovery of up to $80 \%$ ) were obtained, when less concentrated samples requiring shorter electrolysis times were employed. In neither case IR bands other than those of the starting material and its reduction product(s) were present in the 2200 to $1500 \mathrm{~cm}^{-1}$ range throughout the experiment.

UV/Vis spectroelectrochemical investigations on the reduction of $\mathbf{2 b}$ (ESI, †Fig. S2) yields results that also compare well to those obtained with the sulfur and selenium substituted allenylidene complexes. The intense absorption band of the ruthenabutatriene chromophore is shifted from the visible to the near UV region of the spectrum and appears as a 


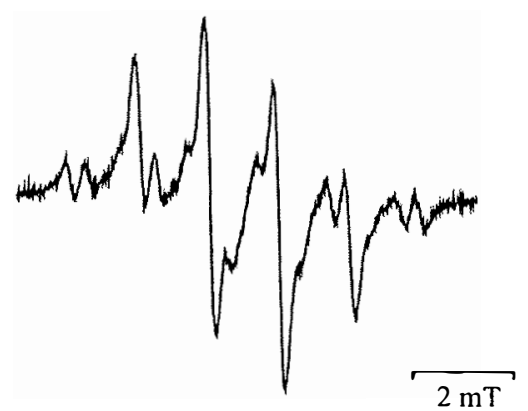

Fig. 6 EPR spectrum obtained upon electrochemical reduction of complex 2b.

low-energy shoulder at $c a .336 \mathrm{~nm}$ superimposed on the intense absorption of the $n \rightarrow \pi^{*}$ transition of the aryl substituted phosphine ligands (Table 3). ${ }^{38}$ We note that neutral alkynyl complexes of ruthenium typically show absorptions at similar energies as is exemplified by trans $-\left[\mathrm{Cl}(\mathrm{dppm})_{2} \mathrm{Ru}-\mathrm{C} \equiv\right.$

$=308 \mathrm{~nm}),{ }^{39}\left[\mathrm{Cp}\left(\mathrm{PPh}_{3}\right)_{2} \mathrm{Ru}-\mathrm{C} \equiv \mathrm{CPh}\right]\left(\lambda_{\max }=311 \mathrm{~nm}\right)$ and $\left[\mathrm{Cp}\left(\mathrm{PPh}_{3}\right)_{2} \mathrm{Ru}-\mathrm{C} \equiv \mathrm{C}-\mathrm{C}_{6} \mathrm{H}_{4} \mathrm{Br}-4\right]\left(\lambda_{\max }=325 \mathrm{~nm}\right){ }^{40}$

It is still not clear whether any of the newly formed bands belongs to the reduced form of the parent allenylidene complex or we are dealing with two different species arising from further chemical reactions of the authentical reduced species. We have however, been able to characterize the primarily formed neutral radical by EPR techniques. Upon electrolytic reduction at reduced temperature $(253 \mathrm{~K})$ a resolved EPR signal at a $g$-value of 1.9959 was detected which irreversibly decays with time (Fig. 6). The splitting pattern could be reproduced by invoking coupling to three $S=1 / 2$ nuclei with $A=15.0 \mathrm{G}\left(\mathrm{CH}_{3}\right)$ and two pairs of inequivalent $S=1 / 2$ nuclei with coupling constants of 10.1 and $14.0 \mathrm{G}(\mathrm{P})$ but without any coupling to the $S=1$ nitrogen atom. The spin densities calculated for the model complex trans $-\left[\mathrm{Cl}\left(\mathrm{PH}_{3}\right)_{4} \mathrm{Ru}=\mathrm{C}=\mathrm{C}=\mathrm{C}\left\{\mathrm{N}\left(\mathrm{CH}_{3}\right)_{2}\right\}\left(\mathrm{CH}_{3}\right)\right]^{\circ}$ are $0.046(\mathrm{Ru}), 0.403\left(\mathrm{C}_{u}\right),-0.142\left(\mathrm{C}_{\beta}\right), 0.505\left(\mathrm{C}_{\text {. }}\right)$ and 0.140 $\left\{\mathrm{N}\left(\mathrm{CH}_{3}\right)_{2}\right\}{ }^{16}$ The absence of any coupling to the nitrogen atom thus comes as a surprise. The presence of two different sets of to two ${ }^{31} \mathrm{P}$ nuclei each, however, clearly shows that the element of asymmetry (i.e. the sterically demanding organic ligand) is still present in the reduced species and that rotation around the $\mathrm{C}=\mathrm{N}$ bond is still slow. Moreover, it argues against any fragmentation as does the overall chemical reversibility of the reduction $\rightarrow$ reoxidation sequence.

\section{Theoretical investigations of the rotational barrier in amino- allenylidene complexes}

Despite the distinct iminium alkynyl character of cationic aminoallenylidene complexes electronic effects need not be the only and not even the most important contributor to the energy barrier associated with rotation around the $\mathrm{C}_{\gamma} \mathrm{N}$ bond. Unfavourable steric interactions between the phenyl substituents on the diphosphine ligands and the substituents attached to the nitrogen atom may also play an important role. In order to disseminate between these two contributions we have undertaken a computational study employing the hydrogen substituted complex $\left[\mathrm{Cl}(\mathrm{dhpm}){ }_{2} \mathrm{Ru}=\mathrm{C}=\mathrm{C}=\mathrm{C}\{\mathrm{N}(\mathrm{CH}\right.$

(dhpm $=\mathrm{H}_{2} \mathrm{PCH}_{2} \mathrm{PH}_{2}$ ) as a model of a sterically unhindered derivative. Unlike the $\mathrm{PH}_{3}$ substituted complex employed in our previous studies ${ }^{16}$ this dhpm model includes the effect of the angular distortion exerted by the rigid four-membered chelate It is, however, largely devoid of steric hindrance and may thus be viewed to represent the electronic portion of the rotation barrier.

Optimization yielded a ground state geometry with essentially identical features as observed for the experimental ones such as short $\mathrm{C}_{\alpha} \mathrm{C}_{\beta}$ and $\mathrm{C}_{\gamma} \mathrm{N}$ bonds and a planar coordinated iminium type nitrogen atom (see Table 4). Unlike in the real
Table 4 Calculated bond lengths $(\AA)$ and angles $\left({ }^{\circ}\right)$ for the optimized structures of trans- $\left[\mathrm{Cl}(\mathrm{dhpm})_{2} \mathrm{RuC}_{3}\left(\mathrm{CH}_{3}\right)\left\{\mathrm{N}\left(\mathrm{CH}_{3}\right)_{2}\right\}\right]^{+}$in the in-plane and orthogonal orientations of the $\mathrm{NR}_{2}$ moiety

\begin{tabular}{|c|c|c|c|c|}
\hline \multirow[b]{2}{*}{$\theta$} & \multicolumn{2}{|c|}{ G98/B3LYP } & \multicolumn{2}{|c|}{$\mathrm{ADF} / \mathrm{BP}$} \\
\hline & 0 & 90 & 0 & 90 \\
\hline $\mathrm{Ru}-\mathrm{Cl}$ & 2.541 & 2.529 & 2.492 & 2.476 \\
\hline $\mathrm{Ru}-\mathrm{P}$ & 2.422 & 2.436 & 2.347 & 2.360 \\
\hline $\mathrm{Ru}-\mathrm{C}_{a}$ & 1.922 & 1.882 & 1.938 & 1.904 \\
\hline $\mathrm{C}_{u}-\mathrm{C}_{\beta}$ & 1.253 & 1.268 & 1.255 & 1.270 \\
\hline $\mathrm{C}_{\beta}-\mathrm{C}_{q}$ & 1.377 & 1.344 & 1.374 & 1.346 \\
\hline $\mathrm{C}_{y}-\mathrm{C}\left(\mathrm{CH}_{3}\right)$ & 1.511 & 1.506 & 1.509 & 1.505 \\
\hline C. $-\mathrm{N}$ & 1.342 & 1.434 & 1.347 & 1.439 \\
\hline $\mathrm{N}-\mathrm{C}\left(\mathrm{CH}_{3}\right)$ & 1.469 & 1.471 & 1.472 & 1.481 \\
\hline $\mathrm{Cl}-\mathrm{Ru}-\mathrm{C}_{u}$ & 179.7 & 179.4 & 179.2 & 178.8 \\
\hline $\mathrm{Ru}-\mathrm{C}_{u}-\mathrm{C}_{\beta}$ & 179.8 & 178.4 & 178.1 & 177.6 \\
\hline $\mathrm{C}_{\alpha}-\mathrm{C}_{\beta}{ }^{\prime}-\mathrm{C}_{\gamma}{ }^{\prime}$ & 175.4 & 177.8 & 176.3 & 177.5 \\
\hline $\mathrm{C}_{\beta}-\mathrm{C}_{\gamma}-\mathrm{N}$ & 121.0 & 118.1 & 121.0 & 117.7 \\
\hline
\end{tabular}

structure, however, the $\mathrm{RuC}_{3} \mathrm{R}$ and the $\mathrm{NR}_{2}$ moieties are strictly coplanar in the dhpm model complex. Starting from this geometry the $\mathrm{N}\left(\mathrm{CH}_{3}\right)_{2}$ group was rotated around the $\mathrm{C}_{\gamma} \mathrm{N}$ bond, the rotation being measured by the torsional angle $\mathrm{C}_{\beta} \mathrm{C}_{\gamma} \mathrm{NC}\left(\mathrm{CH}_{3}\right)$. The energy change associated with $\mathrm{CN}$ rotation was calculated for every $10^{\circ}$ change under the premise that the $\mathrm{C}_{\gamma} \mathrm{N}\left(\mathrm{CH}_{3}\right)_{2}$ entity retains its planarity during rotation. An energy maximum was obtained for a torsional angle of $90^{\circ}$, i.e. an orthogonal orientation of the $\mathrm{N}\left(\mathrm{CH}_{3}\right)_{2}$ moiety with respect to the $\mathrm{RuC}_{3}\left(\mathrm{CH}_{3}\right) \mathrm{N}$ plane. Our results indicate an energy barrier of $148.8 \mathrm{~kJ} \mathrm{~mol}^{-1}$, which is substantially larger than the experimental value.

Geometry optimization of the orthogonal rotameric form revealed, however, a lower energy structure 109.3 (G98/B3LYP) or 108.8 (ADF/BP) $\mathrm{kJ} \mathrm{mol}^{-1}$ above the global minimum. As shown in Fig. 7, it differs from the restricted geometry one in that the nitrogen atom is nearly tetrahedrally coordinated and the $\mathrm{C}_{.,} \mathrm{N}$ bond length is increased from 1.342 to $1.434 \AA$ (Table 4). The tetrahedral environment around the nitrogen
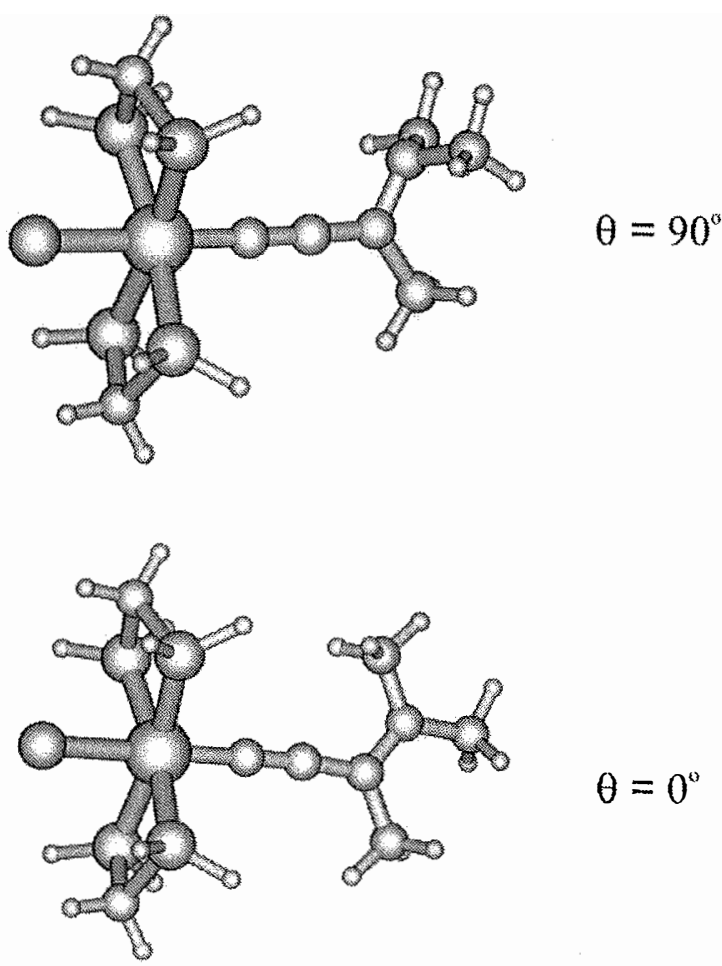

Fig. 7 Optimized structures for trans-[Cl(dhpm $)_{2} \mathrm{RuC}_{3}\left\{\mathrm{~N}\left(\mathrm{CH}_{3}\right)_{2}\right\}$ $\left.\left(\mathrm{CH}_{3}\right)\right]^{+}$in the planar and orthogonal orientations. 
atom indicates that in the orthogonal orientation the nitrogen lone pair and the $\pi$-system of the $\mathrm{RuC}_{3}$ entity are electronically decoupled. Qualitatively speaking, one might then expect the orthogonal rotameric form to more closely resemble a genuine cumulenic structure than is the case for the ground state structure, where the nitrogen lone pair is delocalized into the unsaturated $\pi$-system. Interatomic distances of both optimized forms as calculated by the ADF/BP and the G98/B3LYP levels of theory are compared in Table 4. Upon rotation of the $\mathrm{NR}_{2}$ moiety to the orthogonal orientation the $\mathrm{RuC}_{u}$ bond contracts by $4 \mathrm{pm}$. The $\mathrm{C}_{41} \mathrm{C}_{\beta}$ bond is somewhat elongated and the $\mathrm{C}_{k 3} \mathrm{C}_{\text {. }}$ bond is compressed with respect to the planar iminium alkyny structure. These structure changes, albeit small, are in qualitative agreement with a higher allenylidene character of the orthogonal form.

We have also calculated the structure of trans-[Cl(dppm $)_{2}$ $\left.\mathrm{RuC}_{3}\left\{\mathrm{~N}\left(\mathrm{CH}_{3}\right)_{2}\right\}\left(\mathrm{CH}_{3}\right)\right]^{4}$, a model that is even closer to complex $2 \mathbf{d}$ studied by $\mathrm{X}$-ray crystallography. The calculated bond parameters are provided in Table 1 and compared to the experimental values. The overall agreement between these data sets is remarkable. Replacement of the hydrogen atoms on the phosphine ligands by phenyl rings reproduces two important features of the experimental structure that were not seen in the dhpm model complex. Firstly, it induces a lowering of the symmetry such that all RuP bond lengths are now different. Moreover, the $\mathrm{N}\left(\mathrm{CH}_{3}\right)_{2}$ entity is now rotated out of the $\mathrm{ClRuC}_{3} \mathrm{NC}$-plane. The calculated torsional angle $\mathrm{C}(2)-\mathrm{C}(3)$ $\mathrm{N}-\mathrm{C}(5)$ is $-11.0^{\circ}$ and slightly exceeds the experimental value of $-7.3^{\circ}$. We note, that the degree of out-of-plane rotation strongly depends on the orientation of the phenyl rings which is slightly different in the calculated and the experimental structures. This latter observation shows that steric repulsion between the NRR' group and the phenyl substituents on the phosphine ligands is responsible for this out-of-plane distortion.

\section{Conclusions}

Aminoallenylidene complexes trans- $\left[\mathrm{Cl}(\mathrm{dppm})_{2} \mathrm{RuC}_{3}\left(\mathrm{NRR}^{\prime}\right)\right.$ $\left.\left(\mathrm{CH}_{3}\right)\right]^{+}$are obtained from the regioselective addition of secondary amines to trans $-\left[\mathrm{Cl}(\mathrm{dppm})_{2} \mathrm{Ru}=\mathrm{C}=\mathrm{C}=\mathrm{C}=\mathrm{CH}_{2}\right]^{\dagger}$. Unsymmetrically substituted amines give rise to $Z / E$ isomeric mixtures, where the $E$ isomer with the sterically more demanding amine substituent pointing away from the metal dominates. The $E / Z$ isomeric ratio increases with a larger size difference between the unlike substituents $\mathrm{R}$ and $\mathrm{R}^{\prime}$. Rotation around the $\mathrm{CN}$ bond is slow due to a high energy barrier separating the two rotamers, which points to a prevalence of the iminium alkynyl resonance form. This finds support from the $\mathrm{X}$-ray structure analysis of the $Z$ isomer of the (benzylmethyl)methylamine derivative 2d. Dynamic ${ }^{31} \mathrm{P}$ NMR spectroscopy gave a barrier of about $85 \mathrm{~kJ} \mathrm{~mol}^{-1}$ in good agreement with the values observed for donor substituted organic iminium salts. The issue of $\mathrm{NR}_{2}$ rotation was also addressed by DFT calculations on the trans- $\left[\mathrm{Cl}(\mathrm{dhpm})_{2} \mathrm{RuC}_{3}\left\{\mathrm{~N}\left(\mathrm{CH}_{3}\right)_{2}\right\}\left(\mathrm{CH}_{3}\right)\right]^{+}$model complex (dhpm $\left.=\mathrm{H}_{2} \mathrm{PCH}_{2} \mathrm{PH}_{2}\right)$. Our results indicate that rotation around the iminium type $\mathrm{CN}$ bond decouples the nitrogen lone pair and the $\pi$-system of the allenylidene ligand resulting in a significantly longer $\mathrm{CN}$ bond and a tetrahedrally coordinated nitrogen atom.

\section{Experimental}

\section{General reaction conditions}

All reactions were performed under argon atmosphere but no special precautions as to exclude air or moisture were required during work-up. Common solvents were appropriately dried, distilled under argon and stored over molecular sieves under an argon atmosphere. Butadiyne was prepared as detailed in a previous publication ${ }^{21}$ and cis- $\mathrm{RuCl}_{2}(\mathrm{dppm})_{2}$ according to the literature. ${ }^{41}$ Column chromatography was performed in waterjacketed columns $(4 \times 20 \mathrm{~cm})$ on silica gel (Merck 60$)$ as the stationary phase.

\section{Instrumentation}

IR: Perkin-Elmer Paragon 1000 PC FT-IR. NMR: Bruker AC 250. Spectra were recorded using solutions in $5 \mathrm{~mm}$ sample tubes. UV/Vis: Shimadzu UV-160 or Omega 10 from Bruins Instruments. Measurements were performed in Quartz glass cuvettes of $1 \mathrm{~cm}$ optical path length. Electrochemistry: Potentiostat EG\&G 273 A driven by the EG\&G 250 software package. The cell construction and data analysis was as detailed elsewhere. ${ }^{21}$ Working electrodes: BAS platinum microelectrode $1 \mathrm{~mm}$ diameter or glassy carbon microelectrode $1.6 \mathrm{~mm}$ diameter. All potentials are given relative to the internal ferrocene/ ferrocenium couple. Spectroelectrochemistry: OTTLE cell as described by Hartl and coworkers. ${ }^{42}$ EPR-spectroscopy: Bruker ESP 3000 spectrometer, HP frequency counter $5350 \mathrm{~B}$, Bruker NMR gaussmeter ER $035 \mathrm{M}$ and continuous flow cryostat ESR 900 from Oxford Instruments for low temperature work.

\section{Calculations}

Ground-state electronic structure calculations have been performed by density-functional theory (DFT) methods using the Amsterdam Density Functional (ADF2000.2) 43,44 $^{4}$ and Gaussian $98^{45}$ program packages. Within Gaussian-98 Dunning's valence double- $\zeta$ functions ${ }^{46}$ with polarization functions were used for $\mathrm{C}, \mathrm{N}$ and $\mathrm{H}$ atoms and quasirelativistic effective core pseudo-potentials and corresponding optimized basis functions for $\mathrm{P}^{47} \mathrm{Cl}^{47}$ and $\mathrm{Ru}^{48}$ atoms. Hybrid Becke's three-parameter functional with Lee, Yang and Parr correlation functional (B3LYP) ${ }^{49}$ was used in Gaussian 98 calculations (G98/B3LYP). Within the ADF program Slater type orbital (STO) basis sets were used. Within phenyl substituents basis sets of single- $\zeta$ quality for $\mathrm{C}$ and $\mathrm{H}$ atoms were used while triple- $\zeta$ quality basis sets with polarization functions for $\mathrm{H}, \mathrm{C}, \mathrm{N}, \mathrm{P}, \mathrm{Cl}$ and $\mathrm{Ru}$ were employed for the remaining part of the system. Inner shells were treated within the frozen-core approximation ( $1 \mathrm{~s}$ for $\mathrm{C}$ and $\mathrm{N}$, 1s-2p for $\mathrm{P}$ and $\mathrm{Cl}, 1 \mathrm{~s}-3 \mathrm{~d}$ for $\mathrm{Ru}$ ). Local density approximation (LDA) with VWN parametrization of electron gas data including Becke's gradient correction ${ }^{50}$ to the local exchange expression in conjunction with Perdew's gradient correction ${ }^{51}$ to the LDA correlation was used (ADF/BP). The scalar relativistic (SR) zero-order regular approximation (ZORA) was used within this study. For the calculation of the rotational barrier the real complex was approximated by a model system where the $\mathrm{PPh}_{2}$ entities were replaced by $\mathrm{PH}_{2}$ groups. The calculations on this model have been performed by both $\mathrm{ADF} / \mathrm{BP}$ and G98/B3LYP methods. ADF/BP was utilized for geometry optimization of $\left[\mathrm{Cl}(\mathrm{dppm})_{2} \mathrm{RuCCC}\left\{\mathrm{N}\left(\mathrm{CH}_{3}\right)_{2}\right\}\left(\mathrm{CH}_{3}\right)\right]^{+}$.

\section{Syntheses and characterization}

A representative procedure for the synthesis of complexes $2 \mathbf{a}-\mathbf{e}$ is as follows: cis-[ $\left[\mathrm{RuCl}_{2}(\mathrm{dppm})_{2}\right](180 \mathrm{mg}, 0.181 \mathrm{mmol})$ and $\mathrm{NaSbF}_{6}$ (191 mg, $0.74 \mathrm{mmol}$ ) were dissolved/suspended in $50 \mathrm{ml}$ of dichloromethane and excess butadiyne was added via a precooled pipette. CAUTION: Butadiyne should be handled and stored under rigorous exclusion of air and at temperatures below $230 \mathrm{~K}$. The mixture was stirred for $c a .30$ min until the solution phase colour had changed to intense green. The appropriate amine was then added ( $c a .6$ eq.) and stirring was continued at ambient temperature until occasional IR control indicated constant intensity of the strong "allenylidene" band (typically 2-3 days). The mixture was filtered over a papertipped cannula and the solvent removed in vacuo, leaving an intense coloured, somewhat oily or tarry residue. This was washed with copious amounts of ether and then hexanes in order to remove the excess amine and then dried under reduced 
pressure. This crude product was employed for the determination of the $E / Z$ isomer distribution by ${ }^{1} \mathrm{H}$ and ${ }^{31} \mathrm{P} \mathrm{NMR}$ spectroscopy. Further purification was achieved by column chromatography employing $\mathrm{CH}_{2} \mathrm{Cl}_{2}-\mathrm{CH}_{3} \mathrm{CN} 25: 1-10: 1$ $(\mathrm{v} / \mathrm{v})$ as the mobile phase. Collecting the intense orange-red or greenish-yellow band in two or three portions mostly resulted in partial enrichment of one of the isomers with respect to the original isomer distribution. The solvents were removed and the powdery residues further purified by reprecipitation/recrystallization from $\mathrm{CH}_{2} \mathrm{Cl}_{2}-\mathrm{Et}_{2} \mathrm{O}$. In the case of the iminostilbene complex $\mathbf{2 b}$ several reprecipitation steps were required in order to remove the last traces of the amine while in the case of the phenothiazine derived complex $2 \mathrm{c}$ the excess amine was removed by vacuum sublimation.

trans $-\left[\mathrm{Cl}(\mathrm{dppm})_{2} \mathrm{Ru}=\mathrm{C}=\mathrm{C}=\mathrm{C}\left(\mathrm{NEt}_{2}\right)\left(\mathrm{CH}_{3}\right)\right]^{+} \mathrm{SbF}_{6}{ }^{-}$

(2a). (a) Procedure as detailed above. Yield: $174 \mathrm{mg}(72 \%)$ Anal Found: C, 55.62; H, 4.46; N, 1.18. Calc. for $\mathrm{C}_{58} \mathrm{H}_{57} \mathrm{ClF}_{6} \mathrm{~N}$ $\mathrm{P}_{4} \mathrm{RuSb}$ : C, 55.10; $\mathrm{H}, 4.54 ; \mathrm{N}, 1.11 \%$. IR $(\mathrm{KBr}) / \mathrm{cm}^{-1}: v(\mathrm{CCC})$ 1984 (vs), v(C=N) 1556 (s), v( $\left.\mathrm{SbF}_{6}^{-}\right) 694$ (s), 657 (vs). ${ }^{1} \mathrm{H} \mathrm{NMR}$ $\left(\mathrm{CDCl}_{3}\right): \delta 0.54\left[\mathrm{t},{ }^{3} J(\mathrm{H}, \mathrm{H}) 7.20 \mathrm{~Hz}, 3 \mathrm{H}, \mathrm{CH}_{3}(\mathrm{Z})\right], 0.95[\mathrm{t}$, $\left.{ }^{3} \mathrm{~J}(\mathrm{H}, \mathrm{H}) 7.25 \mathrm{~Hz}, 3 \mathrm{H}, \mathrm{CH}_{3}(E)\right], 1.15\left[\mathrm{~s}, 3 \mathrm{H}, \mathrm{CH}_{3}\right.$ ] 2.61 [quart, ${ }^{3} \mathrm{~J}(\mathrm{H}, \mathrm{H}) 7.20 \mathrm{~Hz}, 2 \mathrm{H}, \mathrm{CH}_{2}(\mathrm{Z})$ ], 3.18 [quart, ${ }^{3} \mathrm{~J}(\mathrm{H}, \mathrm{H}) 7.25 \mathrm{~Hz}$ $2 \mathrm{H}, \mathrm{CH}_{2}(E)$ ], 4.80 [dquint, ${ }^{2} J(\mathrm{H}, \mathrm{H}) 14.9,{ }^{2} J(\mathrm{P}, \mathrm{H})={ }^{4} J\left(\mathrm{P}^{\prime}, \mathrm{H}\right)$ $4.15 \mathrm{~Hz}, 2 \mathrm{H}, \mathrm{CH}_{2}$ (dppm)], 5.15 [dquint, ${ }^{2} J(\mathrm{H}, \mathrm{H}) 14.9 \mathrm{~Hz}$ $\left.{ }^{2} J(\mathrm{P}, \mathrm{H})={ }^{4} J\left(\mathrm{P}^{\prime}, \mathrm{H}\right) 4.5 \mathrm{~Hz}, 2 \mathrm{H}, \mathrm{CH}_{2}(\mathrm{dppm})\right], 7.14\left[\mathrm{t},{ }^{3} J(\mathrm{H}, \mathrm{H})\right.$ $7.1 \mathrm{~Hz}, 8 \mathrm{H}, \operatorname{aryl}-\mathrm{H}(\mathrm{dppm})], 7.31[\mathrm{~m}, 20 \mathrm{H}$, aryl- $\mathrm{H}(\mathrm{dppm})], 7.41$ $\left(\mathrm{t},{ }^{3} \mathrm{~J}(\mathrm{H}, \mathrm{H}) 7.1 \mathrm{~Hz}, 4 \mathrm{H}\right.$, aryl- $\left.\mathrm{H}(\mathrm{dppm})\right], 7.53[\mathrm{~m}, 8 \mathrm{H}$, aryl- $\mathrm{H}$ (dppm)]. ${ }^{13} \mathrm{C}\left\{{ }^{1} \mathrm{H}\right\}$ NMR $\left(\mathrm{CD}_{3} \mathrm{CN}\right): \delta 12.53,12.61\left[\mathrm{~s}, \mathrm{CH}_{3}(\mathrm{Et})\right]$ $24.2\left[\mathrm{~s}, \mathrm{CH}_{3}\right], 44.4\left[\mathrm{~s}, \mathrm{NCH}_{2}(E)\right], 47.8\left[\mathrm{~s}, \mathrm{NCH}_{2}(Z)\right], 48.7$ [quint, $J(\mathrm{P}, \mathrm{C}) 11.1 \mathrm{~Hz}, \mathrm{CH}_{2}$ (dppm)], 119.1 (quint, ${ }^{3} J(\mathrm{P}, \mathrm{C}) 1.7$ $\mathrm{Hz}, \mathrm{C}_{\beta}$ ] $127.8,128.4$ [quint, $J(\mathrm{P}, \mathrm{C}) 2.4 \mathrm{~Hz}, m-\mathrm{C}_{6} \mathrm{H}_{5}$ ], 129.9 , 130.5 [s, $p-\mathrm{C}_{6} \mathrm{H}_{5}$ ] 132.4 [quint, $J(\mathrm{P}, \mathrm{C}) 11.7 \mathrm{~Hz}, i p s o-\mathrm{C}_{6} \mathrm{H}_{5}$ ] 132.9 [quint, $J(\mathrm{P}, \mathrm{C}) 3.1 \mathrm{~Hz}, o-\mathrm{C}_{6} \mathrm{H}_{5}$ ] 133.0 [quint, $J(\mathrm{P}, \mathrm{C}) 2.9 \mathrm{~Hz}$, $o-\mathrm{C}_{6} \mathrm{H}_{5}$ ], 134.0 [quint, $J(\mathrm{P}, \mathrm{C}) 11.3 \mathrm{~Hz}$, ipso- $\mathrm{C}_{6} \mathrm{H}_{5}$ ] 154.2 [quint, ${ }^{4} J(\mathrm{P}, \mathrm{C}) 0.8 \mathrm{~Hz}, \mathrm{C}_{y}$ ] 204.3 [quint, ${ }^{2} J(\mathrm{P}, \mathrm{C}) 13.9 \mathrm{~Hz}, \mathrm{C}_{\alpha}$ ] ${ }^{31} \mathrm{P}\left\{{ }^{1} \mathrm{H}\right\}$ NMR $\left(\mathrm{CDCl}_{3}\right): \delta-8.7[\mathrm{~s}, \mathrm{P}(\mathrm{dppm})]$. UV/Vis $\left(\lambda_{\max } / \mathrm{nm},(\log \varepsilon)\right)$ $\left(\mathrm{CH}_{3} \mathrm{CN}\right.$ ): 208 (4.80), 230 (sh, 4.70), 260 (4.49), 387 (4.33), 460 (sh, 3.11 ), 620 (2.55); $\left(\mathrm{CH}_{2} \mathrm{Cl}_{2}\right): 266$ (4.65), 396 (4.15), 467 (sh, 3.23), $623(2.59)$.

(b) From 4-diethylaminomethyl-2,5-dimethylphenol. A suspension of 1 (175 mg, $0.186 \mathrm{mmol}$ ) and $\mathrm{NaSbF}_{6}(192 \mathrm{mg}$, $0.744 \mathrm{mmol}$ ) in $45 \mathrm{ml}$ of chlorobenzene was treated with excess butadiyne. After the solution phase had taken on a green coloration, $154 \mathrm{mg}(0.744 \mathrm{mmol})$ of the amine was added. The solution was stirred under ambient conditions for 4 days until the developing IR band at $1994 \mathrm{~cm}^{-1}$ had reached constant intensity. Excess $\mathrm{NaSbF}_{6}$ and $\mathrm{NaCl}$ were removed by filtration the solvent was distilled off under reduced pressure. The oily residue was washed with ether and hexanes, dried in vacuo and the crude, powdery product purified graphy. The yield of pure product was $60 \%$.

trans $-\left[\mathrm{Cl}(\mathrm{dppm})_{2} \mathrm{Ru}=\mathrm{C}=\mathrm{C}=\mathrm{C}\left\{\mathrm{N}\left(\mathrm{C}_{6} \mathrm{H}_{4} \mathrm{CH}=\right)_{2}\right\}\left(\mathrm{CH}_{3}\right)\right]^{+} \mathrm{SbF}_{6}{ }^{-}$ (2b). Yield: $140 \mathrm{mg}(53 \%)$. Anal. Found: C, 58.79; H, 4.08; N, 0.99. Calc. for $\mathrm{C}_{68} \mathrm{H}_{57} \mathrm{ClF}_{6} \mathrm{NP}_{4} \mathrm{RuSb}$ : C, $59.00 ; \mathrm{H}, 4.15 ; \mathrm{N}$, $1.01 \%$. IR (KBr)/cm $\mathrm{cm}^{-1}$ : v(CCC) $1953(\mathrm{vs}), v(\mathrm{C}=\mathrm{N}) 1493(\mathrm{~m})$, $v\left(\mathrm{SbF}_{6}{ }^{-}\right) 694(\mathrm{~s}), 657(\mathrm{vs}) .{ }^{1} \mathrm{H}$ NMR $\left(\mathrm{CD}_{2} \mathrm{Cl}_{2}\right): \oint 0.89[\mathrm{~s}, 3 \mathrm{H}$, $\mathrm{CH}_{3}$ ], 4.86 [dquint, ${ }^{2} J(\mathrm{H}, \mathrm{H}) 14.9 \mathrm{~Hz},{ }^{2} J(\mathrm{P}, \mathrm{H})={ }^{4} J\left(\mathrm{P}^{\prime}, \mathrm{H}\right) 4.6 \mathrm{~Hz}$, $2 \mathrm{H}, \mathrm{CH}_{2}(\mathrm{dppm})$ ], 5.11 [dquint, ${ }^{2} J(\mathrm{H}, \mathrm{H}) 14.7 \mathrm{~Hz},{ }^{2} J(\mathrm{P}, \mathrm{H})=$ $\left.{ }^{4} J\left(\mathrm{P}^{\prime}, \mathrm{H}\right) 4.6 \mathrm{~Hz}, 2 \mathrm{H}, \mathrm{CH}_{2}(\mathrm{dppm})\right], 5.60\left[\mathrm{~d},{ }^{3} \mathrm{~J}(\mathrm{H}, \mathrm{H}) 7.6 \mathrm{~Hz}, 1 \mathrm{H}\right.$, $=\mathrm{CH}], 6.85\left[\mathrm{~d},{ }^{3} \mathrm{~J}(\mathrm{H}, \mathrm{H}) 11.6 \mathrm{~Hz}, 1 \mathrm{H},=\mathrm{CH}\right], 6.94\left[\mathrm{~d},{ }^{3} J(\mathrm{H}, \mathrm{H})\right.$ $7.6 \mathrm{~Hz}, 1 \mathrm{H},=\mathrm{CH}], 7.04\left[\mathrm{~d},{ }^{3} \mathrm{~J}(\mathrm{H}, \mathrm{H}) 11.6 \mathrm{~Hz}, 1 \mathrm{H},=\mathrm{CH}\right], 7.18[\mathrm{~m}$, $8 \mathrm{H}$, aryl-H (dppm)], 7.24-7.40 [m, 23H, aryl-H], 7.45-7.52 [m, $9 \mathrm{H}$, aryl-H], $7.64\left[\mathrm{t},{ }^{3} J(\mathrm{H}, \mathrm{H}) 7.4 \mathrm{~Hz}, 2 \mathrm{H}\right.$, aryl-H], $7.74[\mathrm{~m}, 4 \mathrm{H}$, aryl-H]. ${ }^{13} \mathrm{C}\left\{{ }^{1} \mathrm{H}\right\}$ NMR $\left(\mathrm{CD}_{2} \mathrm{Cl}_{2}\right): \delta 27.7\left[\mathrm{~s}, \mathrm{CH}_{3}\right.$ ], 46.6 [quint, $\left.J(\mathrm{P}, \mathrm{C}) 11.3 \mathrm{~Hz}, \mathrm{CH}_{2}(\mathrm{dppm})\right], 124.8,125.2$ [s, C4,4' (iminostilbene)], $127.9\left[\mathrm{t}, J(\mathrm{P}, \mathrm{C}) 4.7 \mathrm{~Hz}, m-\mathrm{C}_{6} \mathrm{H}_{5}\right], 128.0[\mathrm{t}, J(\mathrm{P}, \mathrm{C})=$ $\left.5.3 \mathrm{~Hz}, m-\mathrm{C}_{6} \mathrm{H}_{5}\right], 128.60,128.64\left[\mathrm{t}, J(\mathrm{P}, \mathrm{C}) 4.7 \mathrm{~Hz}, m-\mathrm{C}_{6} \mathrm{H}_{5}\right]$, $128.65,129.29,129.44,129.56,129.82,130.10 .130 .13,130.23$,
$130.25,130.43,130.52$ [s, $p-\mathrm{C}_{6} \mathrm{H}_{5}, \mathrm{CH}$ (iminostilbene)], 131.4 [tt, $J(\mathrm{P}, \mathrm{C}) 20.0,4.2 \mathrm{~Hz}$, ipso- $\mathrm{C}_{6} \mathrm{H}_{5}$ ], 131.5 [s, C (iminostilbene)], 131.7 [s, CH (iminostilbene)], $132.00[\mathrm{t}, J(\mathrm{P}, \mathrm{C})=6.1 \mathrm{~Hz}, o-$ $\mathrm{C}_{6} \mathrm{H}_{5}$ ], 132.04 [C (iminostilbene)], 132.50 (tt, $J(\mathrm{P}, \mathrm{C})$ 19.0, 4.7 $\mathrm{Hz}$, ipso- $\mathrm{C}_{6} \mathrm{H}_{5}$ ] 132.60 [tt, $J(\mathrm{P}, \mathrm{C}) 19.5,3.7 \mathrm{~Hz}$, ipso- $\mathrm{C}_{6} \mathrm{H}_{5}$ ], $133.0\left(\mathrm{t}, J(\mathrm{P}, \mathrm{C}) 5.8 \mathrm{~Hz}, o-\mathrm{C}_{6} \mathrm{H}_{5}\right], 133.6\left[\mathrm{t}, J(\mathrm{P}, \mathrm{C}) 6.3 \mathrm{~Hz}, o-\mathrm{C}_{6} \mathrm{H}_{5}\right]$, $134.6\left[\mathrm{t}, J(\mathrm{P}, \mathrm{C}) 6.8 \mathrm{~Hz}, o-\mathrm{C}_{6} \mathrm{H}_{5}\right.$ ], $134.8(\mathrm{tt}, J(\mathrm{P}, \mathrm{C}) 19.3,3.7 \mathrm{~Hz}$, ipso- $\mathrm{C}_{6} \mathrm{H}_{5}$ ], 138.1, 140.8 [s, C (iminostilbene)], 155.6 [br, $\mathrm{C}_{\mathrm{y}}$ ], 229.1 [quint, ${ }^{2} J(\mathrm{P}, \mathrm{C}) 13.2 \mathrm{~Hz}, \mathrm{C}_{n}$ ] $\left(\mathrm{C}_{\beta}\right.$ was not observed $)$. ${ }^{31} \mathrm{P}\left\{{ }^{1} \mathrm{H}\right\} \mathrm{NMR}\left(\mathrm{CD}_{2} \mathrm{Cl}_{2}\right): \delta-6.7\left[\mathrm{AA}^{\prime}\right.$ part of an $\mathrm{AA}^{\prime} \mathrm{BB}^{\prime}$ spin system], -8.0 [BB' part of an $\mathrm{AA}^{\prime} \mathrm{BB}^{\prime}$ spin system, all $\mathrm{P}$ $(\mathrm{dppm})]$. UV/Vis $\left(\lambda_{\max } / \mathrm{nm}(\log \varepsilon)\right)\left(\mathrm{CH}_{3} \mathrm{CN}\right): 207$ (4.95), 230 (sh, 4.83), 266 (4.71), 300 (sh, 4.11), 423 (4.38), 505 (sh, 2.98); $\left(\mathrm{CH}_{2} \mathrm{Cl}_{2}\right): 268$ (4.71), 304 (sh, 4.08), 427 (4.38), 506 (sh, 2.96), 695 (2.08).

trans $-\left[\mathrm{Cl}(\mathrm{dppm})_{2} \mathrm{Ru}=\mathrm{C}=\mathrm{C}=\mathrm{C}\left\{\mathrm{N}\left(\mathrm{C}_{6} \mathrm{H}_{4}\right)_{2} \mathrm{~S}\right\}\left(\mathrm{CH}_{3}\right)\right]^{+} \mathrm{SbF}_{6}^{-} \quad$ (2c). Yield: $132 \mathrm{mg}, 53 \%$. Anal. Found: $\mathrm{C}, 56.99 ; \mathrm{H}, 4.15, \mathrm{~N}, 0.87$. Calc. for $\mathrm{C}_{66} \mathrm{H}_{55} \mathrm{ClF}_{6} \mathrm{NP}_{4} \mathrm{RuSSb}$ : C, $57.01 ; \mathrm{H}, 3.99 ; \mathrm{N}: 1.01 \%$. IR $(\mathrm{KBr}) / \mathrm{cm}^{-1}: v(\mathrm{CCC}) 1941(\mathrm{vs}), v(\mathrm{C}=\mathrm{N}) 1492(\mathrm{~m}), v\left(\mathrm{SbF}_{6}{ }^{-}\right)$ 694 (s), 658 (vs). ${ }^{1} \mathrm{H}$ NMR $\left(\mathrm{CD}_{2} \mathrm{Cl}_{2}\right): \delta 1.02\left[\mathrm{~s}, 3 \mathrm{H}, \mathrm{CH}_{3}\right]$, 4.73 [dquint, ${ }^{2} J(\mathrm{H}, \mathrm{H}) 14.9 \mathrm{~Hz},{ }^{2} J(\mathrm{P}, \mathrm{H})={ }^{4} J\left(\mathrm{P}^{\prime}, \mathrm{H}\right) 4.6 \mathrm{~Hz}$, $2 \mathrm{H}, \mathrm{CH}_{2}(\mathrm{dppm})$ ], 5.10 [dquint, ${ }^{2} J(\mathrm{H}, \mathrm{H}) 14.9 \mathrm{~Hz},{ }^{2} J(\mathrm{P}, \mathrm{H})=$ $\left.{ }^{4} J\left(\mathrm{P}^{\prime}, \mathrm{H}\right) 4.6 \mathrm{~Hz}, 2 \mathrm{H}, \mathrm{CH}_{2}(\mathrm{dppm})\right], 5.91\left[\mathrm{~d},{ }^{3} J(\mathrm{H}, \mathrm{H}) 7.8 \mathrm{~Hz}\right.$, $1 \mathrm{H}$, phenothiazine), $6.97\left(\mathrm{vt},{ }^{3} \mathrm{~J}(\mathrm{H}, \mathrm{H}) 7.8 \mathrm{~Hz}, 1 \mathrm{H}\right.$, phenothiazine), 7.10-7.60 [m, $46 \mathrm{H}$, phenyl (dppm, phenothiazine)]. ${ }^{13} \mathrm{C}\left\{{ }^{1} \mathrm{H}\right\}$ NMR $\left(\mathrm{CD}_{2} \mathrm{Cl}_{2}\right): \delta 29.4\left[\mathrm{~s}, \mathrm{CH}_{3}\right], 46.6$ [quint, $J(\mathrm{P}, \mathrm{C})$ $\left.11.3 \mathrm{~Hz}, \mathrm{CH}_{2}(\mathrm{dppm})\right], 126.8$ [s, br, $\mathrm{C}_{\beta}$ ] $126.0-134.1$ [several $\mathrm{m}$, phenyl (dppm) and $\mathrm{CH}$ (phenothiazine)], 137.0, 139.9 [s, $\mathrm{C}^{1}, \mathrm{C}^{6}$ (phenothiazine)], 152.7 [s, br, $\mathrm{C}_{y}$ ], 235.3 [quint, ${ }^{2} J(\mathrm{P}, \mathrm{C})$ $\left.13.1 \mathrm{~Hz}, \mathrm{C}_{u}\right] .{ }^{31} \mathrm{P}\left\{{ }^{1} \mathrm{H}\right\} \mathrm{NMR}\left(\mathrm{CD}_{2} \mathrm{Cl}_{2},\right): \delta-6.3\left[\mathrm{AA}^{\prime}\right.$ part of an $\mathrm{AA}^{\prime} \mathrm{BB}^{\prime}$ spin system], -9.7 [BB' part of an $\mathrm{AA}^{\prime} \mathrm{BB}^{\prime}$ spin system, all $\mathrm{P}(\mathrm{dppm})]$. UV/Vis $\left(\lambda_{\max } / \mathrm{nm}(\log \varepsilon)\right)\left(\mathrm{CH}_{3} \mathrm{CN}\right): 210$ (4.83), 226 (sh, 4.81), 258 (4.67), 320 (sh, 3.90), 445 (4.21), 733 (3.64); $\left(\mathrm{CH}_{2} \mathrm{Cl}_{2}\right): 260$ (4.68), 320 (sh, 3.85), 452 (4.22), 740 (3.63).

\section{ZIE-trans $-\left[\mathrm{Cl}(\mathrm{dppm})_{2} \mathrm{Ru}=\mathrm{C}=\mathrm{C}=\mathrm{C}\left(\mathrm{NMeCH}_{2} \mathrm{Ph}\right)\left(\mathrm{CH}_{3}\right)\right]^{+} \mathrm{SbF}_{6}^{-}$} (2d). Yield: $145 \mathrm{mg}(0.110 \mathrm{mmol}, 58 \%)$ Anal. Found: C, 56.38; $\mathrm{H}, 4.28 ; \mathrm{N}, 1.05$. Calc. for $\mathrm{C}_{62} \mathrm{H}_{57} \mathrm{ClF}_{6} \mathrm{NP}_{4} \mathrm{RuSb}$ : C, 56.75; $\mathrm{H}$, 4.38; N: $1.07 \%$. IR (KBr) $/ \mathrm{cm}^{-1}$ : v(CCC) $1991(\mathrm{vs}), v(\mathrm{C}=\mathrm{N}) 1565$ $(\mathrm{m}), v\left(\mathrm{SbF}_{6}{ }^{-}\right) 695(\mathrm{~s}), 657(\mathrm{vs}) . Z-2 \mathrm{~d}:{ }^{1} \mathrm{H}$ NMR $\left(\mathrm{CDCl}_{3}\right): \delta 1.20$ [s, 3H, $\left.\mathrm{CH}_{3}\right], 2.68\left[\mathrm{~s}, 3 \mathrm{H}, \mathrm{NCH}_{3}\right], 3.93\left[\mathrm{~s}, 2 \mathrm{H}, \mathrm{NCH}_{2}\right.$ ], 4.79 [dquint, ${ }^{2} J(\mathrm{H}, \mathrm{H}) 14.9 \mathrm{~Hz},{ }^{2} J(\mathrm{P}, \mathrm{H})={ }^{4} J\left(\mathrm{P}^{\prime}, \mathrm{H}\right) 4.3 \mathrm{~Hz}, 2 \mathrm{H}, \mathrm{CH}_{2}$ (dppm)], 5.06-5.15 [m, 2H, $\left.\mathrm{CH}_{2}(\mathrm{dppm})\right], 6.67[\mathrm{~m}, 2 \mathrm{H}, \mathrm{CH}$ (Bz)]. ${ }^{13} \mathrm{C}\left\{{ }^{1} \mathrm{H}\right\}$ NMR $\left(\mathrm{CD}_{2} \mathrm{Cl}_{2}\right): \delta 24.9\left[\mathrm{~s}, \mathrm{CH}_{3}\right], 37.2\left[\mathrm{~s}, \mathrm{NCH}_{3}\right]$, 48.7 [quint, $J(\mathrm{P}, \mathrm{C}) 11.1 \mathrm{~Hz}, \mathrm{CH}_{2}(\mathrm{dppm})$ ], 58.6 [s, $\mathrm{NCH}_{2}$ ], 119.1 [quint, ${ }^{3} J(\mathrm{P}, \mathrm{C})=1.8 \mathrm{~Hz}, \mathrm{C}_{\beta}$ ] 127.8 [quint, $J(\mathrm{P}, \mathrm{C}) 2.6 \mathrm{~Hz}$, $m-\mathrm{C}_{6} \mathrm{H}_{5}$ ], 128.5 [quint, $J(\mathrm{P}, \mathrm{C}) 2.3 \mathrm{~Hz}, m-\mathrm{C}_{6} \mathrm{H}_{5}$ ], $130.00,130.4$, [s, p- $\mathrm{C}_{6} \mathrm{H}_{5}$ ], 132.25 [quint, $J(\mathrm{P}, \mathrm{C}) 11.6 \mathrm{~Hz}$, ipso $\left.-\mathrm{C}_{6} \mathrm{H}_{5}\right), 132.7$ [quint, $\left.J(\mathrm{P}, \mathrm{C}) 3.2 \mathrm{~Hz}, o-\mathrm{C}_{6} \mathrm{H}_{5}\right], 133.4\left[\mathrm{~m}, o-\mathrm{C}_{6} \mathrm{H}_{5}\right], 133.6$ (quint, $J(\mathrm{P}, \mathrm{C})$ $11.1 \mathrm{~Hz}$, ipso- $\mathrm{C}_{6} \mathrm{H}_{5}$ ], 154.3 [br, C.], 206.2 [quint, ${ }^{2} J(\mathrm{P}, \mathrm{C}) 13.7 \mathrm{~Hz}$, $\left.\mathrm{C}_{u}\right) .{ }^{31} \mathrm{P}\left\{{ }^{1} \mathrm{H}\right\}$ NMR $\left(\mathrm{CD}_{2} \mathrm{Cl}_{2}\right): \delta-8.0[\mathrm{~s}, \mathrm{P}(\mathrm{dppm})] . E-2 \mathrm{~d}:{ }^{1} \mathrm{H}$ NMR $\left(\mathrm{CDCl}_{3}\right): \delta 1.28\left[\mathrm{~s}, 3 \mathrm{H}, \mathrm{CH}_{3}\right], 2.13\left[\mathrm{~s}, 3 \mathrm{H}, \mathrm{NCH}_{3}\right], 4.46[\mathrm{~s}$, $2 \mathrm{H}, \mathrm{NCH}_{2}$ ], 4.96 [dquint, ${ }^{2} J(\mathrm{H}, \mathrm{H}) 15.1 \mathrm{~Hz},{ }^{2} J(\mathrm{P}, \mathrm{H})={ }^{4} J\left(\mathrm{P}^{\prime}, \mathrm{H}\right)$ $\left.4.1 \mathrm{~Hz}, 2 \mathrm{H}, \mathrm{CH}_{2}(\mathrm{dppm})\right], 5.06-5.15\left[\mathrm{~m}, 2 \mathrm{H}, \mathrm{CH}_{2}(\mathrm{dppm})\right], 6.81$ $[\mathrm{m}, 2 \mathrm{H}, \mathrm{CH}(\mathrm{Bz})] \cdot{ }^{13} \mathrm{C}\left\{{ }^{1} \mathrm{H}\right\}$ NMR $\left(\mathrm{CD}_{2} \mathrm{Cl}_{2}\right): \delta 24.3\left[\mathrm{~s}, \mathrm{CH}_{3}\right], 41.2$ [s, $\mathrm{NCH}_{3}$ ] 48.1 [quint, $J(\mathrm{P}, \mathrm{C}) 10.9 \mathrm{~Hz}, \mathrm{CH}_{2}(\mathrm{dppm})$ ], 55.9 [s, $\mathrm{NCH}_{2}$ ], 120.9 [quint, ${ }^{3} J(\mathrm{P}, \mathrm{C})=1.6 \mathrm{~Hz}, \mathrm{C}_{\mathrm{\beta}}$ ] 127.9 [quint, $J(\mathrm{P}, \mathrm{C})$ $\left.2.6 \mathrm{~Hz}, m-\mathrm{C}_{6} \mathrm{H}_{5}\right), 128.4$ [quint, $J(\mathrm{P}, \mathrm{C}) 2.4 \mathrm{~Hz}, m-\mathrm{C}_{6} \mathrm{H}_{5}$ ], 130.01 , $130.5,\left[\mathrm{~s}, p-\mathrm{C}_{6} \mathrm{H}_{5}\right.$ ], 132.34 [quint, $J(\mathrm{P}, \mathrm{C}) 11.6 \mathrm{~Hz}$, ipso- $\mathrm{C}_{6} \mathrm{H}_{5}$ ], 132.8 [quint, $J(\mathrm{P}, \mathrm{C}) 3.2 \mathrm{~Hz}, o-\mathrm{C}_{6} \mathrm{H}_{5}$ ] $133.4\left[\mathrm{~m}, o-\mathrm{C}_{6} \mathrm{H}_{5}\right.$ ] 133.9 [quint, $J(\mathrm{P}, \mathrm{C}) 11.3 \mathrm{~Hz}$, ipso- $\mathrm{C}_{6} \mathrm{H}_{5}$ ], $156.3\left[\mathrm{br}, \mathrm{C}_{\text {. }}\right.$ ], 209.8 [quint, $\left.{ }^{2} J(\mathrm{P}, \mathrm{C}) 13.7 \mathrm{~Hz}, \mathrm{C}_{11}\right] \cdot{ }^{31} \mathrm{P}\left\{{ }^{1} \mathrm{H}\right\}$ NMR $\left(\mathrm{CD}_{2} \mathrm{Cl}_{2}\right): \delta-8.7[\mathrm{~s}, \mathrm{P}$ $(\mathrm{dppm})]$. The following resonance signals could not be attributed to the individual isomers: ${ }^{1} \mathrm{H}$ NMR $\delta 7.18[\mathrm{~m}, 10 \mathrm{H}]$, $7.25-7.38[\mathrm{~m}, 27 \mathrm{H}], 7.52[\mathrm{~m}, 8 \mathrm{H}]$ all aryl-H (dppm, benzyl). ${ }^{13} \mathrm{C}$ NMR: $\delta 126.5,127.8,128.9,129.0,133.0$ aryl-C of the benzyl substituent. UV/Vis $\left(\lambda_{\max } / \mathrm{nm}(\log \varepsilon)\right)\left(\mathrm{CH}_{2} \mathrm{Cl}_{2}\right): 267$ (4.61), 400 (4.18), 464 (sh, 3.59), 500 (sh, 3.52), 627 (2.76). 
ZIE-trans- $\left[\mathrm{Cl}(\mathrm{dppm}){ }_{2} \mathrm{Ru}=\mathrm{C}=\mathrm{C}=\mathrm{C}\left(\mathrm{NMeCH}_{2}\right.\right.$ anthracenyl)$\left.\left(\mathrm{CH}_{3}\right)\right]^{+} \mathrm{SbF}_{6}{ }^{-}$(2e). Yield: $59 \%$. Anal. Found: C, 57.86; $\mathrm{H}, 4.22$ $\mathrm{N}, 1.01$. Calc. for $\mathrm{C}_{70} \mathrm{H}_{61} \mathrm{ClF}_{6} \mathrm{NP}_{4} \mathrm{RuSb}$ : C, 59.53; H, 4.35; 0.99\%. IR (KBr)/cm $\mathrm{cm}^{-1}$ : v(CCC) $1993(\mathrm{vs}), 1561 v(\mathrm{C}=\mathrm{N})(\mathrm{m})$, $v\left(\mathrm{SbF}_{6}{ }^{-}\right) 696(\mathrm{~s}), 657$ (vs). Z-2e: ${ }^{1} \mathrm{H}$ NMR $\left(\mathrm{CDCl}_{3}\right): \delta 1.27[\mathrm{~s}$ $\left.3 \mathrm{H}, \mathrm{CH}_{3}\right], 2.27\left[\mathrm{~s}, 3 \mathrm{H}, \mathrm{NCH}_{3}\right], 5.19\left[\mathrm{~s}, 2 \mathrm{H}, \mathrm{NCH}_{2}\right] .{ }^{13} \mathrm{C}\left\{{ }^{1} \mathrm{H}\right\}$ $\operatorname{NMR}\left(\mathrm{CD}_{2} \mathrm{Cl}_{2}\right): \delta 24.8\left[\mathrm{~s}, \mathrm{CH}_{3}\right], 37.6\left[\mathrm{~s}, \mathrm{NCH}_{3}\right], 47.5\left[\mathrm{~s}, \mathrm{NCH}_{2}\right]$ 47.6 [quint, $J(\mathrm{P}, \mathrm{C}) 11.6 \mathrm{~Hz}, \mathrm{CH}_{2}(\mathrm{dppm})$ ], $120.1\left[\mathrm{br}, \mathrm{C}_{\beta}\right.$ ], 130.4 , $130.8,\left[\mathrm{~s}, p-\mathrm{C}_{6} \mathrm{H}_{5}\right.$ ] 132.4 [quint, $J(\mathrm{P}, \mathrm{C}) 11.6 \mathrm{~Hz}$, ipso- $\mathrm{C}_{6} \mathrm{H}_{5}$ ] $132.6\left[\mathrm{~m}, o-\mathrm{C}_{6} \mathrm{H}_{5}\right.$ ] 133.3 [quint, $J(\mathrm{P}, \mathrm{C}) 3.2 \mathrm{~Hz}, o-\mathrm{C}_{6} \mathrm{H}_{5}$ ], 154.3 [br, $\mathrm{C}_{\gamma}$ ], 206.2 (quint, $\left.{ }^{2} J(\mathrm{P}, \mathrm{C}) 13.7 \mathrm{~Hz}, \mathrm{C}_{t}\right] .{ }^{31} \mathrm{P}\left\{{ }^{1} \mathrm{H}\right\}$ NMR $\left(\mathrm{CDCl}_{3}\right): \delta-8.6[\mathrm{~s}, \mathrm{P}(\mathrm{dppm})] . E-2 \mathrm{e}:{ }^{1} \mathrm{H} \mathrm{NMR}\left(\mathrm{CDCl}_{3}\right): \delta 1.10$ $\left[\mathrm{s}, 3 \mathrm{H}, \mathrm{CH}_{3}\right], 2.44\left[\mathrm{~s}, 3 \mathrm{H}, \mathrm{NCH}_{3}\right], 4.69\left[\mathrm{~s}, 2 \mathrm{H}, \mathrm{NCH}_{2},\right] .{ }^{13} \mathrm{C}\left\{{ }^{1} \mathrm{H}\right\}$ NMR $\left(\mathrm{CD}_{2} \mathrm{Cl}_{2}\right): \delta 25.0\left[\mathrm{~s}, \mathrm{CH}_{3}\right.$ ], $35.4\left[\mathrm{~s}, \mathrm{NCH}_{3}\right.$ ], 48.4 [quint $\left.J(\mathrm{P}, \mathrm{C}) 12.1 \mathrm{~Hz}, \mathrm{CH}_{2}(\mathrm{dppm})\right], 51.0\left[\mathrm{~s}, \mathrm{NCH}_{2}\right], 119.8\left[\mathrm{br}, \mathrm{C}_{\beta}\right]$ $130.5,130.9$ [s, $p-\mathrm{C}_{6} \mathrm{H}_{5}$ ] 132.2 (quint, $J(\mathrm{P}, \mathrm{C}) 11.6 \mathrm{~Hz}$, ipso$\mathrm{C}_{6} \mathrm{H}_{5}$ ], 132.6 [m, $o-\mathrm{C}_{6} \mathrm{H}_{5}$ ], 133.4 [quint, $J(\mathrm{P}, \mathrm{C}) 3.2 \mathrm{~Hz}, o-\mathrm{C}_{6} \mathrm{H}_{5}$ ] 133.8 (quint, $J(\mathrm{P}, \mathrm{C}) 11.6 \mathrm{~Hz}$, ipso- $\mathrm{C}_{6} \mathrm{H}_{5}$ ] 156.2 [br, $\mathrm{C}$.], 210.2 [quint, ${ }^{2} J(\mathrm{P}, \mathrm{C}) 13.7 \mathrm{~Hz}, \mathrm{C}_{u}$ ]. ${ }^{31} \mathrm{P}\left\{{ }^{1} \mathrm{H}\right\}$ NMR $\left(\mathrm{CDCl}_{3}\right): \delta-8.1$ [s, P (dppm)]. The following resonance signals could not unambiguously assigned to the individual isomers: ${ }^{1} \mathrm{H}$ NMR $\delta 4.80,4.95$ each $\left[\mathrm{m}, 2 \mathrm{H} \mathrm{CH}_{2}(\mathrm{dppm})\right], 7.00[\mathrm{~m}, 12 \mathrm{H}], 7.10-7.28$ $[\mathrm{m}, 18 \mathrm{H}], 7.37[\mathrm{~m}, 5 \mathrm{H}], 7.42[\mathrm{~m}, 5 \mathrm{H}], 7.80-7-88[\mathrm{~m}, 4 \mathrm{H}]$ $8.15[\mathrm{~m}, 3 \mathrm{H}]$, all aryl-H (dppm, anthracenyl); ${ }^{13} \mathrm{C}\left\{{ }^{1} \mathrm{H}\right\}$ NMR $\delta 127.8,128.4\left[\mathrm{~m}, m-\mathrm{C}_{6} \mathrm{H}_{5}\right], 123.3,124.0,124.3,125.2,125.5$ $126.9,127.1,127.9,129.0,129.5,130.1,130.4,130.5,130.88$ $130.91,130.98,131.03,131.4,131.6,131.7$ all aryl-C (anthracenyl). UV/Vis $\left(\lambda_{\max } / \mathrm{nm}(\log \varepsilon)\right)\left(\mathrm{CH}_{2} \mathrm{Cl}_{2}\right): 259$ (4.57), 274 (sh, 4.55), 335 (4.07), 352 (4.22), 368 (4.38), 388 (4.38), 399 (4.36), 477 (sh, 3.29), 557 (sh, 2.92), 742 (2.23).

\section{$Z I E$-trans $-\left[\mathrm{Cl}(\mathrm{dppm})_{2} \mathrm{Ru}=\mathrm{C}=\mathrm{C}=\mathrm{C}\left(\mathrm{NMe}^{\prime} \mathrm{Bu}\right)\left(\mathrm{CH}_{3}\right)\right]^{+} \mathrm{SbF}_{6}{ }^{-}$}

(2f). This compound was purified by recrystallization from $\mathrm{CHCl}_{3}-\mathrm{Et}_{2} \mathrm{O}$; yield $75 \%$. Anal. Found: $\mathrm{C}, 54.75 ; \mathrm{H}, 4.86 ; \mathrm{N}$, 1.05. Calc. for $\mathrm{C}_{59} \mathrm{H}_{67} \mathrm{ClF}_{6} \mathrm{NP}_{4} \mathrm{RuSb}$ : C, 55.09; H, 5.25; N, $1.09 \%$. IR (K Br) $/ \mathrm{cm}^{-1}: v(\mathrm{CCC}) 1996$ (unsymmetrical band with low energy shoulder, vs), $v(\mathrm{C}=\mathrm{N}) 1586(\mathrm{~m}) . Z$-2f: ${ }^{1} \mathrm{H}$ NMR $\left(\mathrm{CDCl}_{3}\right): \delta 0.87\left[\mathrm{~s}, 3 \mathrm{H}, \mathrm{CH}_{3}\right], 1.27\left[\mathrm{~s}, 9 \mathrm{H}, \mathrm{CH}_{3}\right], 2.77[\mathrm{~s}, 3 \mathrm{H}$ $\mathrm{NCH}_{3}$ ] 4.76 [dquint, ${ }^{2} J(\mathrm{H}, \mathrm{H})=14.9,{ }^{2} J(\mathrm{P}, \mathrm{H})={ }^{4} J\left(\mathrm{P}^{\prime}, \mathrm{H}\right) 4.5 \mathrm{~Hz}$ $2 \mathrm{H}, \mathrm{CH}_{2}$ (dppm)], 4.89-4.97 [m, 2H, $\left.\mathrm{CH}_{2}(\mathrm{dppm})\right] \cdot{ }^{13} \mathrm{C}\left\{{ }^{1} \mathrm{H}\right\}$ NMR $\left(\mathrm{CD}_{2} \mathrm{Cl}_{2}\right): \delta 27.5\left[\mathrm{~s}, \mathrm{C}\left(\mathrm{CH}_{3}\right)_{3}\right], 29.7\left[\mathrm{~s}, \mathrm{CH}_{3}\right], 36.6[\mathrm{~s}$, $\mathrm{NCH}_{3}$ ], 48.7 [quint, $\left.J(\mathrm{P}, \mathrm{C}) 11.1 \mathrm{~Hz}, \mathrm{CH}_{2}(\mathrm{dppm})\right], 63.7$ [s, $C\left(\mathrm{CH}_{3}\right)_{3}$ ] 124.5 [br, $\mathrm{C}_{\beta}$ ], 128.3 [quint, $J(\mathrm{P}, \mathrm{C})=2.6 \mathrm{~Hz}, m-\mathrm{C}_{6} \mathrm{H}_{5}$ ], 129.1 [quint, $J(\mathrm{P}, \mathrm{C})=2.4 \mathrm{~Hz}), 130.4,131.2\left[\mathrm{~s}, p-\mathrm{C}_{6} \mathrm{H}_{5}\right], 132.5$ [quint, $J(\mathrm{P}, \mathrm{C}) 11.6 \mathrm{~Hz}$, ipso- $\mathrm{C}_{6} \mathrm{H}_{5}$ ], 133.4, 133.5 [quint, $J(\mathrm{P}, \mathrm{C})$ $\left.3.2 \mathrm{~Hz}, o-\mathrm{C}_{6} \mathrm{H}_{5}\right), 134.2$ [quint, $J(\mathrm{P}, \mathrm{C}) 11.1 \mathrm{~Hz}$, ipso- $\left.\mathrm{C}_{6} \mathrm{H}_{5}\right), 158.2$ [br, C.] 213.7 [quint, ${ }^{2} J(\mathrm{P}, \mathrm{C})=13.3 \mathrm{~Hz}, \mathrm{C}_{u}$ ]. ${ }^{31} \mathrm{P}\left\{{ }^{1} \mathrm{H}\right\} \mathrm{NMR}$ $\left(\mathrm{CD}_{2} \mathrm{Cl}_{2},\right): \delta-9.1[\mathrm{~s}, \mathrm{P}(\mathrm{dppm})] . E-2 \mathrm{f}:{ }^{1} \mathrm{H}$ NMR $\left(\mathrm{CDCl}_{3}\right): \delta 0.97$ $\left[\mathrm{s}, 3 \mathrm{H}, \mathrm{CH}_{3}\right], 1.36\left[\mathrm{~s}, 9 \mathrm{H}, \mathrm{CH}_{3}\right], 2.18\left[\mathrm{~s}, 3 \mathrm{H}, \mathrm{NCH}_{3}\right], 4.89-4.97$ $\left[\mathrm{m}, 2 \mathrm{H}, \mathrm{CH}_{2}\right.$ (dppm)], 5.11 [dquint, ${ }^{2} J(\mathrm{H}, \mathrm{H}) 14.9 \mathrm{~Hz},{ }^{2} J(\mathrm{P}, \mathrm{H})=$ $\left.{ }^{4} J\left(\mathrm{P}^{\prime}, \mathrm{H}\right) 4.6 \mathrm{~Hz}, 2 \mathrm{H}\right) \cdot{ }^{13} \mathrm{C}\left\{{ }^{1} \mathrm{H}\right\} \quad \mathrm{NMR}\left(\mathrm{CD}_{2} \mathrm{Cl}_{2}\right): \delta 25.4[\mathrm{~s}$ $\mathrm{C}\left(\mathrm{CH}_{3}\right)_{3}$ ], 28.0 [s, $\mathrm{CH}_{3}$ ], 40.2 [s, $\mathrm{NCH}_{3}$ ] 48.5 [quint, $J(\mathrm{P}, \mathrm{C}) 11.1$ $\mathrm{Hz}, \mathrm{CH}_{2}$ (dppm)], 63.0 [s, $\mathrm{C}\left(\mathrm{CH}_{3}\right)_{3}$ ], 123.3 [br, $\mathrm{C}_{\beta}$ ], 128.3 [quint, $J(\mathrm{P}, \mathrm{C}) 2.6 \mathrm{~Hz}, m-\mathrm{C}_{6} \mathrm{H}_{5}$ ], 128.8 [quint, $J(\mathrm{P}, \mathrm{C})=2.4 \mathrm{~Hz}, m-\mathrm{C}_{6} \mathrm{H}_{5}$ ], $130.5,130.9$ [s, p- $\mathrm{C}_{6} \mathrm{H}_{5}$ ] 132.9 [quint, $J(\mathrm{P}, \mathrm{C}) 10.3 \mathrm{~Hz}$, ipso$\mathrm{C}_{6} \mathrm{H}_{5}$ ], 133.2 [quint, $\left.J(\mathrm{P}, \mathrm{C}) 3.2 \mathrm{~Hz}, o-\mathrm{C}_{6} \mathrm{H}_{5}\right), 133.6$ [quint, $J(\mathrm{P}, \mathrm{C})$ $\left.2.9 \mathrm{~Hz}, o-\mathrm{C}_{6} \mathrm{H}_{5}\right], 134.2$ (quint, $J(\mathrm{P}, \mathrm{C}) 11.3 \mathrm{~Hz}$, ipso- $\left.\mathrm{C}_{6} \mathrm{H}_{5}\right], 156.8$ [br, C.] $], 206.8$ [quint, $\left.{ }^{2} J(\mathrm{P}, \mathrm{C}) 13.4 \mathrm{~Hz}, \mathrm{C}_{v},\right) .{ }^{31} \mathrm{P}\left\{{ }^{1} \mathrm{H}\right\}$ NMR $\left(\mathrm{CD}_{2} \mathrm{Cl}_{2}\right): \delta-9.5[\mathrm{~s}, \mathrm{P}(\mathrm{dppm})]$. The following resonance signals could not be assigned to the individual isomers: ${ }^{1} \mathrm{H}$ NMR: $\delta 7.22[\mathrm{~m}, 8 \mathrm{H}], 7.30-7.45[\mathrm{~m}, 24 \mathrm{H}], 7.52,7.65$ each $[\mathrm{m}, 8 \mathrm{H}]$, all aryl-H (dppm). ${ }^{13} \mathrm{C}$ NMR: $\delta$ 123.0, 124.5 [each br, $\mathrm{C}_{\beta}$ ]. The resonance signal of one of the ipso-C-atoms of a dppm ligand for the $Z$-isomer could not be located. UV/Vis $\left(\lambda_{\max } / \mathrm{nm}(\log \varepsilon)\right)$ $\left(\mathrm{CH}_{2} \mathrm{Cl}_{2}\right): 265$ (4.40), 322 (3.87), 338 (3.87), 395 (3.97), 468 (sh, 3.76).

$\mathrm{X}$-Ray analysis of Z-trans-[Cl(dppm) ${ }_{2} \mathrm{Ru}=\mathrm{C}=\mathrm{C}=\mathrm{C}(\mathrm{NMe}$ $\left.\left.\mathrm{CH}_{2} \mathrm{Ph}\right)\left(\mathrm{CH}_{3}\right)\right]^{+} \mathrm{SbF}_{6}^{-}$(2d). Dark yellow blocky crystals were obtained by slow concentration of a solution in $\mathrm{CH}_{2} \mathrm{Cl}_{2}-\mathrm{Et}_{2} \mathrm{O}$
Table 5 Crystallographic data for trans,Z-2d

\begin{tabular}{ll}
\hline Formula & $\mathrm{C}_{62} \mathrm{H}_{37} \mathrm{ClF}_{6} \mathrm{NP}_{4} \mathrm{RuSb}$ \\
$M$ & 1312.24 \\
$T / \mathrm{K}$ & $173(2)$ \\
$\lambda / \AA$ & 0.71073 \\
Crystal system & Monoclinic \\
Space group & $P 2_{1} / c$ \\
$a / \AA$ & $12.8677(9)$ \\
$b / \AA$ & $24.811(3)$ \\
$c / \AA$ & $21.3714(16)$ \\
$\beta /^{\circ}$ & $106.557(4)$ \\
$V I \AA^{3}$ & $6540.3(10)$ \\
$Z$ & 4 \\
$D_{\mathrm{c}} / \mathrm{Mg} \mathrm{m}^{-3}$ & 1.333 \\
$\mu / \mathrm{mm}{ }^{-1}$ & 0.835 \\
$F(000)$ & 2648 \\
Crystal size/mm & $0.3 \times 0.3 \times 0.2$ \\
$\theta$ Range for data collection $/^{\circ}$ & 2.15 to 24.00 \\
Index ranges for data collection & $-1 \leq h \leq 14,-28 \leq k \leq 28$, \\
& $-24 \leq l \leq 23$ \\
No. of retins. measured & 12324 \\
No. of indep. refins. $\left(R_{\text {int }}\right)$ & $10209(0.0422)$ \\
Refinement method & Full-matrix least-squares on $F^{2}$ \\
Data/restraints/parameters & $10209 / 979 / 790$ \\
Goodness-of-fit on $F^{2}$ & 1.030 \\
Final $R$ indices $[I>4 \sigma(I)]$ & $R_{1}=0.0693, w R_{2}=0.1587$ \\
$R$ indices (all data) & $R_{1}=0.1212, w R_{2}=0.1785$ \\
Largest diff. peak and hole/e $\AA^{-3}$ & 0.995 and -0.995 \\
\hline & \\
\hline
\end{tabular}

(5:1) at ambient temperature. Data collection was performed on a Siemens $\mathrm{P} 4$ diffractometer at $173 \mathrm{~K}$. The structure was solved by direct methods employing the SHELX-97 and SHELXS-97 program packages. ${ }^{52}$ Non-hydrogen atoms were refined

is disordered over two positions. Hydrogen atoms were added at calculated positions and assigned isotropic displacement parameters equal to $1.2\left(\mathrm{CH}, \mathrm{CH}_{2}\right)$ or 1.5 times $\left(\mathrm{CH}_{3}\right)$ of the $U_{\text {iso }}$ value of their respective parent carbon atoms and treated with appropriate riding models during the refinement. Other data pertinent to the data collection and structure solution are collected in Table 5 .

CCDC reference number 175409

See http://www.rsc.org/suppdata/dt/b2/b211774f/ for crystallographic data in CIF or other electronic format.

\section{Acknowledgements}

We are grateful to the Deutsche Forschungsgemeinschaft and VW-Stiftung for financial support of this work. We also thank Johnson Matthey Inc. for a generous loan of $\mathrm{RuCl}_{3}$.

\section{References}

1 V. Cadierno, M. P. Gamasa and J. Gimeno, Eur: J. Inorg. Chem., 2001, 571 .

2 M. I. Bruce, Chem. Rev., 1998, 98, 2797.

3 D. Touchard and P. H. Dixneuf, Coord. Chem. Rev., 1998, 178-180, 409

4 H. Werner, Chem. Commun., 1997, 903

5 J. P. Selegue, Organometallics, 1982, 1, 217

6 E.-O. Fischer, H. J. Kalder, A. Frank, F. H. Köhler and G. Huttner, Angew. Chem., 1976, 88, 683

7 M. Duetsch, F. Stein, R. Lackmann, E. Pohl, R. Herbst-Irmer and A.d. Meijere, Chem. Ber., 1992, 125, 2051.

8 F. Stein, M. Duetsch, E. Pohl, R. Herbst-Irmer and A. d. Meijere, Organometallics, 1993, 12, 2556.

9 R. Aumann, B. Jasper and R. Fröhlich, Organometallics, 1995, 14, 3173.

10 G. Roth and H. Fischer, Organometallics, 1996, 15, 1139

11 M. I. Bruce, P. Hinterding, P. J. Low, B. W. Skelton and A. H. White, Chem. Commun., 1996, 1009.

12 M. I. Bruce, P. Hinterding, P. J. Low, B. W. Skelton and A. H. White, J. Chem. Soc, Dalton Trans., 1998, 467.

13 D. Touchard, P. Haquette, A. Daridor, L. Toupet and P. H. Dixneuf, J. Am. Chem. Soc: 1994, 116, 11157. 
14 D. Péron, A. Romero and P. H. Dixneuf, Organometallics, 1995, 14, 3319.

15 R. F. Winter, Organometallics, 1997, 16, 4248.

16 R. F. Winter, K.-W. Klinkhammer and S. Zális, Organometallics, 2001, 20, 1317.

17 J. R. Lomprey and J. P. Selegue, Organometallics, 1993, 12, 616

18 P. Haquette, D. Touchard, L. Toupet and P. Dixneuf, J. Organomet. Chem., 1998, 565, 63

19 V. Guillaume, P. Thominot, F. Coat, A. Mari and C. Lapinte J. Organomet. Chem., 1998, 565, 75 .

20 N. Re, A. Sgamellotti and C. Floriani, Organometallics, 2000, 19 1115.

21 R. F. Winter and F. M. Homung, Organometallics, 1999, 18, 4005.

22 J. Pospísek, M. Pisova and M. Soucek, Collect. Czech. Chem. Commun., 1975, 40, 142.

23 J. Sandström In Dynamic NMR Spectroscopy, Academic Press, London, 1982.

24 H. Günther, NMR-Spektroskopie, Georg Thieme Verlag, Stuttgart, 1992.

25 C. G. McCarty, in The chemistry of the carbon-nitrogen double bond, ed. S. Patai, Interscience Publishers, New York, 1970

26 C. Rabiller, J. P. Renou and G. J. Martin, J. Chem. Soc., Perkin Trans 2, 1977, 536

27 G. Roth, H. Fischer, T. Meyer-Friedrichsen, J. Heck, S. Houbrechts and A. Persoons, Organometallics, 1998, 17, 1511.

28 J. Manna, K. D. John and M. D. Hopkins, Adv. Organomet. Chem, $1995, \mathbf{3 8}, 79$.

29 D. R Lide and H. P. Frederikse, CRC Handbook of Chemistry and Physics, CRC Press, Boca Raton, FL, 76th edn., 1995.

30 M. Svaan and V. D. Parker, Acta Chem. Scand., Ser. B, 1982, 36, 351

31 F. G. Bordwell, X.-M. Zhang and J.-P. Cheng, J. Org. Chem., 1993, 58,6410 .

32 M. D. Ward and J. A. McCleverty, J. Chem. Soc., Dalton Trans., 2002, 275.

33 K. J. Harlow, A. F. Hill and J. D. E. T. Wilton-Ely, J. Chem. Soc., Dalton Trans., 1999, 285.

34 F. Paul, J.-Y. Mevellec and C. Lapinte, J. Chem. Soc., Dalton Trans. 2002,1783

35 R. F. Winter, Eur. J. Inorg. Chem., 1999, 2121.

$36 \mathrm{~S}$. Hartmann, R. F. Winter, T. Scheiring and M. Wanner, J. Organomet. Chem., 2001, 637-639, 240.
37 S. Rigaut, O. Maury, D. Touchard and P. H. Dixneuf, Chem. Commun., 2001, 373.

38 H. Goetz, F. Nerdel and K.-H. Wiechel, Liebigs Ann. Chem., 1963, 665,1 .

39 I. R. Whittall, A. W. McDonagh and M. G. Humphrey, Adv. Organomet. Chem., 1998, 42, 291.

40 I. R. Whittall, M. G. Humphrey, M. Samoc, J. Swiatkiewicz and B. Luther-Davies, Organometallics, 1995, 14, 5493.

41 B. Chaudret, G. Commenges and R. Poilblanc, J. Chem. Soc., Dalton Trans., 1984, 1635.

42 M. Krejcik, M. Danek and F. Hartl, J. Electroanal. Chem., 1991, 317, 179.

43 C. Fonseca Guerra, J. G. Snyders, G. te Velde and E. J. Baerends, Theor. Chim. Acta, 1998, 99, 391.

44 S. J. A. van Gisbergen, J. G. Snijders and E. J. Baerends, Comput. Phys. Commun., 1999, 118, 119

45 M. J. Frisch, G. W. Trucks, H. B. Schlegel, G. E. Scuseria, M. A. Robb, J. R. Cheeseman, V. G. Zakrzewski, J. A. Montgomery, Jr., R. E. Stratmann, J. C. Burant, S. Dapprich, J. M. Millam, A. D. Daniels, K. N. Kudin, M. C. Strain, O. Farkas, J. Tomasi, V. Barone, M. Cossi, R Cammi, B. Mennucci, C. Pomelli, C. Adamo, S. Clifford, J. Ochterski, G. A. Petersson, P. Y. Ayala, Q. Cui, K. Morokuma, D. K. Malick, A. D. Rabuck, K. Raghavachari, J. B. Foresman, J. Cioslowski, J. V. Ortiz, B. B. Stefanov, G. Liu, A. Liashenko, P. Piskorz, I. Komaromi, R. Gomperts, R. L. Martin, D. J. Fox, T. Keith, M. A. Al-Laham, C. Y. Peng, A. Nanayakkara, C. Gonzalez, M. Challacombe, P. M. W. Gill, B. G. Johnson, W. Chen, M. W. Wong, J. L. Andres, M. Head-Gordon, E. S. Replogle and J. A. Pople, GAUSSIAN 98 (Revision A.7), Gaussian, Inc., Pittsburgh, PA, 1998.

46 D. E. Woon and T. H. Dunning, J. Chem. Phys., 1993, 98, 1358.

47 A. Bergner, M. Dolg, W. Kuechle, H. Stoll and H. Preuss, Mol. Phys., 1993, 80, 1431

48 D. Andrae, U. Haeussermann, M. Dolg, H. Stoll and H. Preuss, Theor: Chim. Acta, 1990, 77, 123

49 P. J. Stephens, F. J. Devlin, C. F. Cabalowski and M. J. Frisch, J. Phys. Chem., 1994, 98, 11623 .

50 A. D. Becke, Phys. Rev. $A, 1988,38,3098$.

51 J. P. Perdew, Phys. Rev. A, 1986, 33, 8822

52 G. M. Sheldrick, Institut für Anorganische Chemie der Universität, Tammanstraße 4, Göttingen, 1997. 